\title{
Properties of Cement-Based Materials Containing Cathode-Ray Tube (CRT) Glass Waste as Fine Aggregates-A Review
}

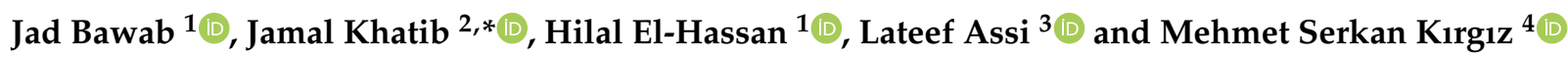 \\ 1 Department of Civil and Environmental Engineering, United Arab Emirates University, \\ Al Ain 15551, United Arab Emirates; 202190186@uaeu.ac.ae (J.B.); helhassan@uaeu.ac.ae (H.E.-H.) \\ 2 Faculty of Engineering, Beirut Arab University, Beirut 11-5020, Lebanon \\ 3 Department of Civil Engineering, Mazaya University College, Nasiriyah 64001, Iraq; lassi@email.sc.edu \\ 4 Department of Architecture, Faculty of Engineering and Natural Sciences, İstanbul Sabahattin Zaim \\ University, İstanbul 3403, Turkey; nakres42@yahoo.com \\ * Correspondence: j.khatib@bau.edu.lb
}

check for

updates

Citation: Bawab, J.; Khatib, J.;

El-Hassan, H.; Assi, L.; Kırgız, M.S.

Properties of Cement-Based Materials

Containing Cathode-Ray Tube (CRT)

Glass Waste as Fine Aggregates-A

Review. Sustainability 2021, 13, 11529.

https://doi.org/10.3390/su132011529

Academic Editors: P. Senthil Kumar,

Dai-Viet N. Vo, N. Selvaraju

and $S$. Ramalingam

Received: 23 July 2021

Accepted: 13 October 2021

Published: 19 October 2021

Publisher's Note: MDPI stays neutral with regard to jurisdictional claims in published maps and institutional affiliations.

Copyright: (c) 2021 by the authors. Licensee MDPI, Basel, Switzerland. This article is an open access article distributed under the terms and conditions of the Creative Commons Attribution (CC BY) license (https:// creativecommons.org/licenses/by/ $4.0 /)$.
Abstract: Among many alternatives to replace sand in cement-based materials, cathode-ray tube (CRT) glass emerges as a suitable replacement for many reasons. This paper provides a state-of-theart review on the use of cathode-ray tube (CRT) glass waste in cement-based concrete and mortar in accordance with PRISMA guidelines. The new aspects of the research are the literature coverage up to 2021 which would make it distinct from other articles. This review would act as a catalyst to use CRT glass waste in concrete mixtures. A total of 61 papers from literature were analyzed with emphasis on the fresh, mechanical, and durability performance of cement-based materials containing CRT glass waste as fine aggregates. The analysis revealed that the majority of the studies agreed that replacing sand with CRT glass waste increased the consistency where the low permeability of the CRT glass caused this effect. Strength of cement-based materials, on the other hand, decreased due to the weaker bond between the cement paste and the aggregates. The low water absorption of the CRT glass defined its effect on the durability properties of cement-based materials, such as drying shrinkage and water absorption capacity, leading to an improved performance. In addition, CRT glass waste activated the alkali-silica reaction in cement-based materials causing undesirable expansion. Additionally, several investigations proposed solutions to mitigate the lead leaching associated with the lead content found in the CRT glass. In general, it was assessed that CRT glass waste could be a valid component in the production of sustainable cement-based materials, especially for radiation shielding applications. The recommendations for future research are also suggested.

Keywords: cathode-ray tubes glass; concrete; mortar; fine aggregates; electronic waste; recycling

\section{Introduction}

Concrete is the second most widely used material in the world [1]. To produce concrete, huge amounts of aggregates, cement, and water and other resources are consumed annually. Using waste or recycled materials in concrete can reduce the amounts of quarried/virgin materials, which can be used to replace cement [2-5] or aggregates [6-10]. Aggregates alone constitute roughly 70 to 80 percent of concrete, by volume, with around 25 to 35 percent of total aggregates produced globally being used in concrete. As such, the demand is noticeably growing, especially in developing countries [11], where construction projects lack environmental impact assessment triggering as a result environmental concerns [12]. In addition to that, the world consumption of aggregates surpasses 40 billion tons annually [13]. The extraction of these large quantities has considerable consequences on biodiversity, landscapes and water supply $[14,15]$. These aggregates are categorized into fine and coarse aggregates. Typically, sand is used as the natural fine aggregate in conventional concrete. Since the extraction levels of sand are beyond the replenishment levels, solutions such as 
avoidance policies, alternative materials, and standards must be exploited to tackle the crisis of sand depletion [16].

Reducing the amount of virgin aggregate in construction application is possible through the use of recycled or waste materials [17]. Sustainable and economical alternatives include: crushed rock sand, industrial byproducts and recycled aggregates [18]. A wide variety of recycled materials can efficiently replace aggregates in concrete, including glass waste. It is a widely used non-biodegradable material with different forms and shapes and versatile applications. Such various applications result in excessive amounts of glass waste each year that require prolonged time periods to break down naturally if landfilled [19-21]. This glass waste is derived from containers, fluorescent lamps, and television screens [22]. The European Union alone generated around 18.3 million tons of waste glass in 2012 [23]. Nevertheless, this waste has a very high potential for recycling and achieved a high recycling rate [24]. In fact, its very low permeability and high hardness of glass can enhance the performance of structural concrete [25].

The United Nations has adopted a sustainable development agenda that includes 17 goals including infrastructure and sustainable cities which are specific to construction [26]. In order to meet some of these goals, a rational utilization of natural resources used in construction is necessary. These include materials recycling which would reduce the amount of virgin materials used. Past research examined the effect of recycling glass as aggregates in cement-based materials. Adaway and Wang [27] stated that using glass waste as a partial replacement of sand, especially at $30 \%$ replacement level, could contribute to the increase of the compressive strength of structural concrete. Another study investigated the effects of replacing fine and coarse aggregates with glass waste in concrete on durability related properties and revealed that the incorporation of glass waste resulted in an improvement in water absorption and carbonation resistance at late curing periods [28]. Additionally, Wang et al. [29] demonstrated that the properties of cement mortar could be maintained when replacing sand with liquid crystal display (LCD) glass at $10-20 \%$ replacement levels. However, some concerns arose regarding the use of glass waste in cement-based materials, in particular the evolution of alkali-silica reaction (ASR) and the weakening of the bond between the hydrated cement and aggregates [30].

The cathode-ray tube (CRT) is made of $85 \%$ glass [31], and could potentially be used in cement-based materials. The use of waste CRT glass in cement-based materials is associated with better environmental practices related to the proper waste management and mitigation of toxic waste disposal [32]. In addition, recycling CRT glass waste in cementbased materials alleviates energy consumption, $\mathrm{CO}_{2}$ emissions, and costs compared to landfilling [33]. As early as 2004, CRT glass waste was used in concrete to replace fine aggregates where two main concerns were highlighted, leaching of heavy metals and ASR [34]. In general, CRT glass waste can be used in different forms in concrete. Some studies used CRT glass waste as a replacement for coarse aggregates in cement-based materials. Pauzi et al. [35] for example used CRT glass waste as coarse aggregates and noted that this replacement increased the slump but drastically decreased compressive, tensile splitting, and flexural strength. Further, Liu et al. [36] replaced both fine and coarse aggregates with different amounts of CRT glass waste. The authors noticed an improvement in consistency and a decrease in strength and drying shrinkage.

Different studies have used CRT glass waste as a supplementary cementitious material (SCM) for its pozzolanic activity. Hilton et al. [37] examined the environmental impact and performance of concrete containing CRT glass and other types of recycled glass powder as partial replacement for cement and found that the compressive strength of concrete was enhanced after one year of curing. Maschio et al. [38] reported an increase in compressive strength and limited ASR when CRT glass of particle size smaller than $500 \mu \mathrm{m}$ wa added to concrete. Grdic et al. [39] investigated self-compacting concrete incorporating CRT glass of particle size less than $125 \mu \mathrm{m}$ and found an improvement in consistency, compressive strength, tensile strength, and adequate durability. Walczak et al. [40] showed that autoclaved aerated concrete using CRT glass waste as SCM had comparable me- 
chanical properties to that of the control mixture without the detection of any harmful chemical compounds.

Owing to the high silica content in the CRT glass waste and ability to reduce the energy costs associated with the milling of glass to produce a powder, nearly most of the experimental studies that incorporated CRT glass in cement-based materials used it as a partial or total substitute for sand only. A number of review papers have already discussed the recycling of CRT glass in building materials [41-44]. However, there is a need for an updated overview that considers the latest research done related to the incorporation of CRT glass in cement-based materials in light of its significance to sustainability. The new aspects of this paper include a full review on the recent developments regarding the use of CRT glass waste in cement-based materials with emphasis on their fresh, mechanical, and durability properties. These properties include consistency, density, compressive, tensile, and flexural strength, modulus of elasticity, drying shrinkage and water absorption, alkali-silica reaction, lead leachability, and radiation shielding. The practicality of using CRT glass waste as fine aggregates in cement mortar and concrete is evaluated based on the results of experimental studies related to this topic in light of its contribution to sustainability. The new aspects of this paper compared with those of previous literature reviews are presented in Table 1.

Table 1. New aspects presented in the study in comparison with previous literature reviews related to the topic.

\begin{tabular}{cc}
\hline Authors & Aspects of the Study \\
\hline Iniaghe and Adie, 2015 [41] & $\begin{array}{c}\text { Management practices of waste CRT monitors including glass } \\
\text { treatment technologies and reuse of CRT glass in cement-based } \\
\text { materials with the coverage of major properties: workability, } \\
\text { strength, expansion due to ASR, and lead leaching. }\end{array}$ \\
\hline Rashad, 2015 [42] & $\begin{array}{c}\text { Fresh, mechanical, and durability properties of cement-based } \\
\text { materials containing CRT glass as fine aggregates with coverage } \\
\text { up to 2015 using 16 references dedicated to this analysis. }\end{array}$ \\
\hline Yao et al., 2018 [43] & $\begin{array}{c}\text { Usage of waste CRT glass in different construction and building } \\
\text { materials, including a general overview of their use in } \\
\text { cement-based materials. }\end{array}$ \\
\hline Qi et al., 2019 [44] & $\begin{array}{c}\text { Recycling routes of CRT glass, with focus on open-loop recycling } \\
\text { and brief overview of their recycling in cement-based materials. }\end{array}$ \\
\hline Current study & $\begin{array}{c}\text { Extensive analysis of the use of CRT glass as fine aggregates in } \\
\text { cement-based materials with emphasis on fresh, mechanical, and } \\
\text { durability properties and a coverage up to 2021 and future } \\
\text { recommendations based on major conclusions. }\end{array}$ \\
\hline
\end{tabular}

\section{Methodology}

This paper is a systematic literature review that presents an overview of the properties of cement mortar and concrete that include CRT glass waste as fine aggregates in accordance with PRISMA guidelines [45]. These guidelines are a set of instructions that facilitate the reporting of systematic literature reviews. For the purpose of identifying relevant papers, keyword searching was carried out using Scopus database. A defined search query was used (Appendix A). As a result of the search criteria, a total of 137 records were obtained. These records were screened to include only the experimental studies that used CRT glass in either cement mortar or concrete, thus excluding 67 records. Then, the remaining records were assessed for eligibility and 49 full-text papers were selected. The bibliography in the selected papers were examined for the detection of further related studies and an additional 12 studies were found eligible. Therefore, a total of 61 full-text papers were selected for the analysis. This is better illustrated in Figure 1. 


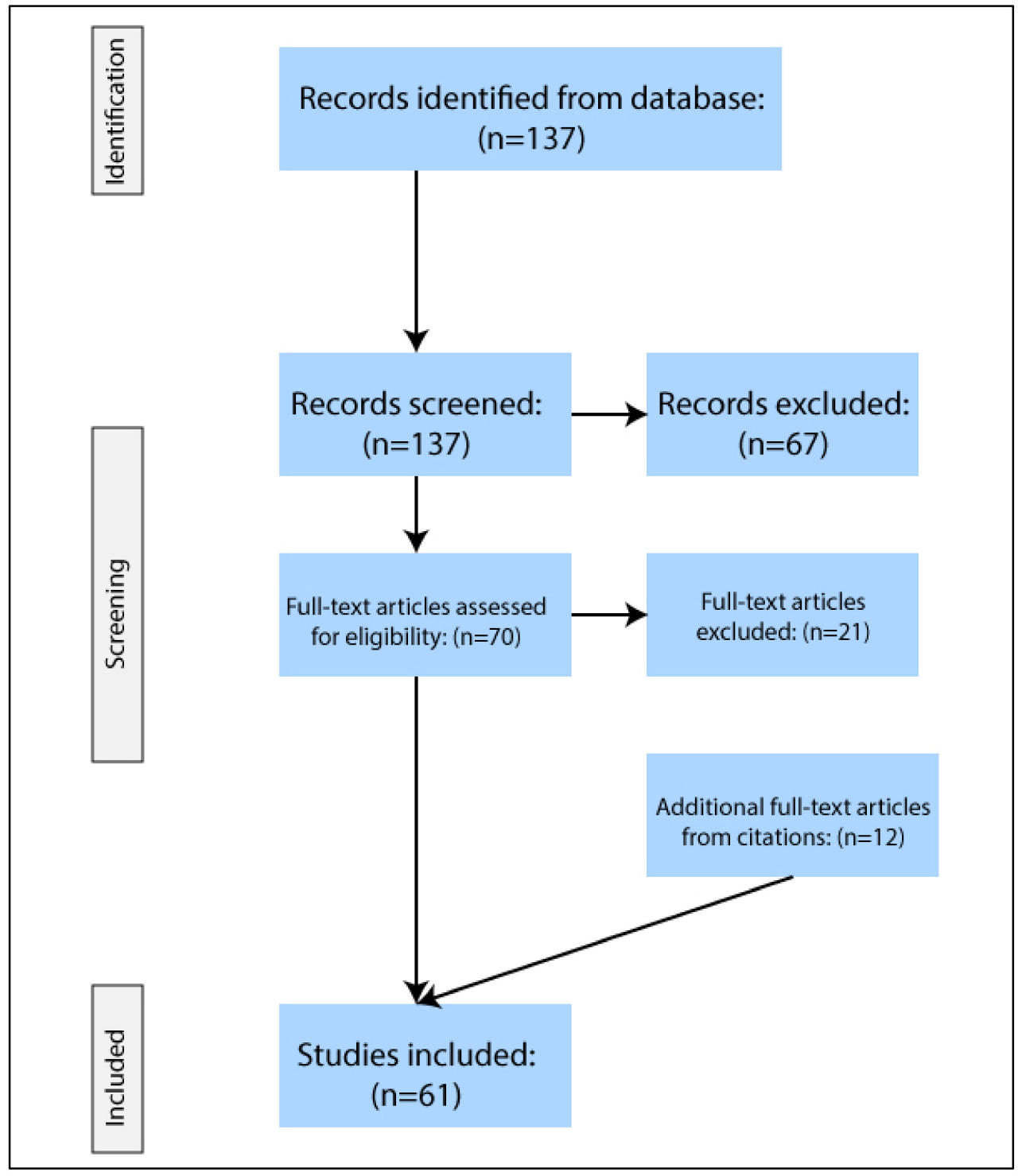

Figure 1. PRISMA flowchart for studies selection.

The papers varied between journal research articles, book sections, and conference papers. They were grouped according to the type of cement-based material and the date of publication to trace the direction of development of the topic. Full texts were screened, and data was then collected from the selected papers and categorized according to the main properties of cement-based materials mentioned earlier. Some studies used chemically treated CRT glass for the removal of its lead content. So, unless otherwise indicated, all "treated CRT glass" mentioned in this paper indicates CRT glass having its lead removed.

Section 3 presents an overview of the current situation of the recycling systems of CRT monitors, whereas Section 4 shows the main characteristics of the CRT monitors with emphasis on the part made of glass. Section 5 discusses the effects of including CRT glass on the consistency of cement mortar and concrete, while Section 6 highlights its impact on the fresh and hardened density. In turn, Section 7 analyzes the change in strength of cement mortar and concrete with the inclusion of CRT glass as fine aggregate. The modulus of elasticity and drying shrinkage are discussed in Sections 8 and 9. The following three sections (10-12) considers durability related properties such as water absorption, alkali silica reaction, and lead leaching. Section 13 debates the prospect of using CRT glass concrete in radiation shielding applications. Finally, Section 14 concludes the paper and suggests recommendations for future research. 


\section{CRT Recycling}

Since the 1950s, CRT has been the main constituent of TVs and computer screens [46,47]. However, with the spread of LCDs and plasma display panels (PMDs), CRT monitors are becoming obsolete [43,47]. This has led to the disposal of huge quantities of CRT monitors mainly in landfill sites and this will possibly continue in the coming decades causing major environmental concerns [48-51]. For example, in China alone, about 43 million tons of CRT monitors were discarded in 2013 [52]. The environmental concern is due to lead and other heavy metals content found in CRT glass [53].

Appropriate recycling of CRT glass should be performed to avoid such environmental problems. There are two categories of recycling CRT: closed-loop recycling and open-loop recycling. Figure 2 summarizes the typical recycling system of CRT glass [31].

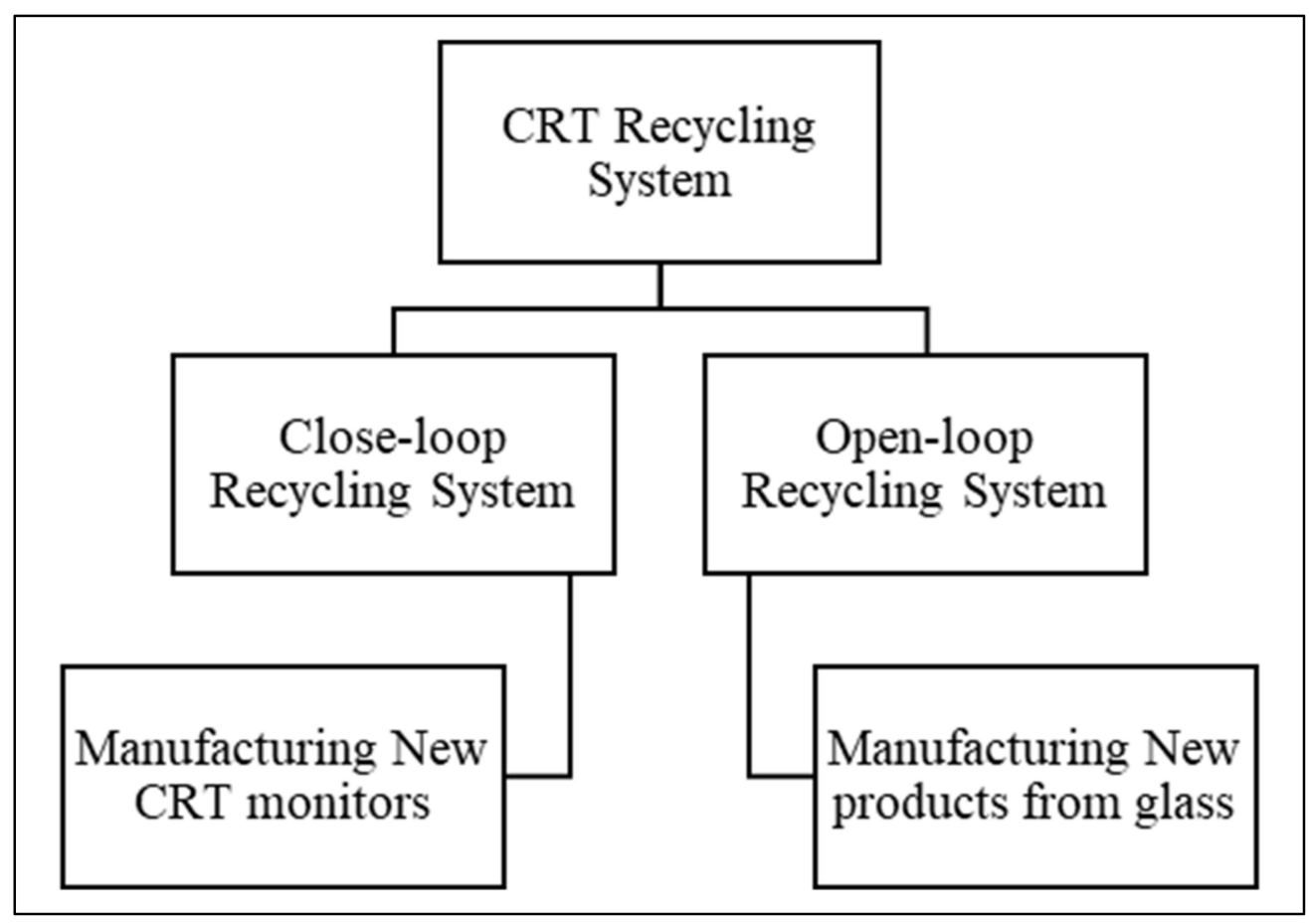

Figure 2. Recycling system of CRT, redrawn from [31].

The first includes the reuse of CRT glass in the manufacture of new CRT glass shells after proper pre-treatments [44]. Yet, due to lower demand of new CRT monitors, this type of recycling is not feasible anymore [54,55]. In contrast, open-loop recycling is a more difficult process [47]. It includes utilizing CRT glass waste in the creation of new products, but it is more feasible since it has an economic and environmental value [53]. New products include construction materials, where richness in silica and low water absorption properties of CRT glass waste makes it a suitable alternative to sand or pozzolan in concrete [43]. Figure 2 summarizes the typical recycling system of CRT glass.

\section{Characteristics of CRT Glass}

The CRT monitor is a vacuum tube that generates image when an electron ray hits a phosphorescent surface $[31,47,53]$. It is made up of three main parts: electron gun, front panel glass, and funnel glass [56]. The front panel, funnel, and neck glass contributes to about $65 \%, 30 \%$, and $5 \%$, respectively [49,57]. Different chemical compositions are found in the various glass components, each containing different chemical and physical forms of lead [47]. Figure 3 illustrates the composition of a typical CRT monitor [58]. 


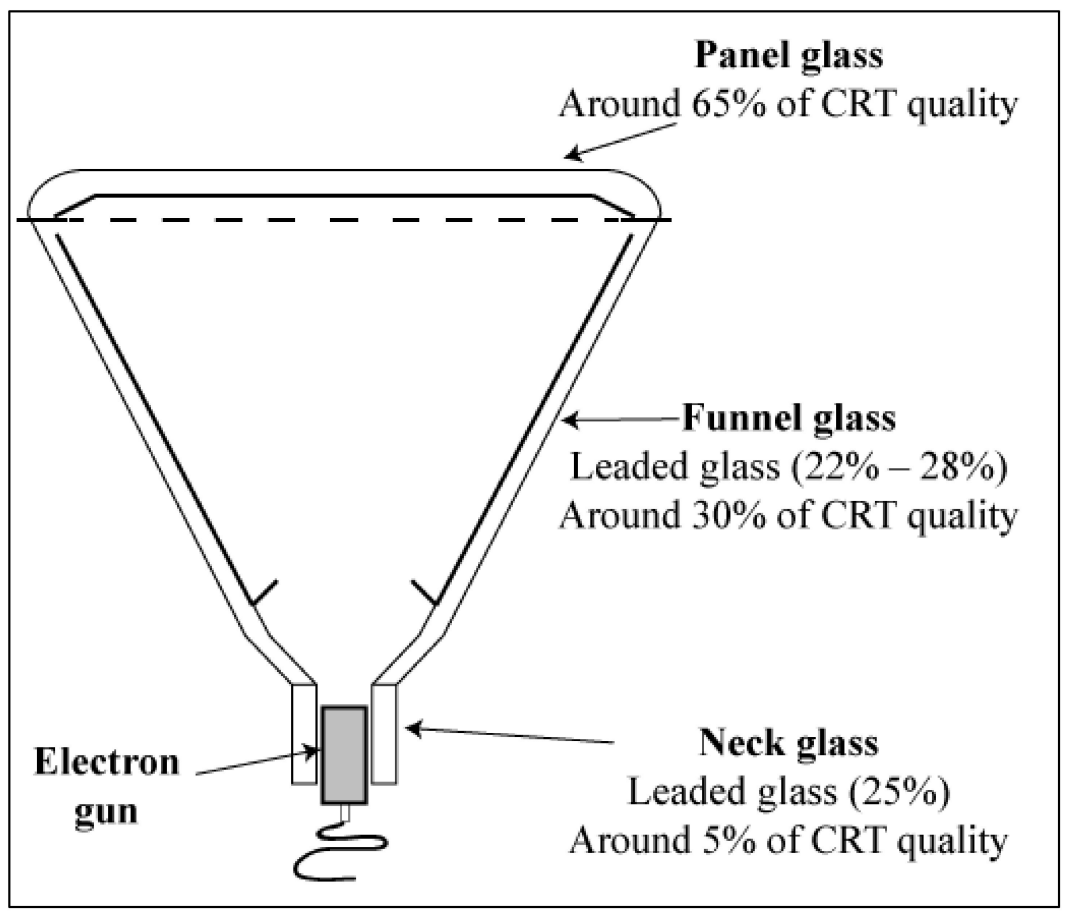

Figure 3. Composition of CRT monitors, redrawn from [58].

In general, CRT monitors can be divided to two categories: monochrome (black and white) and colored CRT. Silica is the main component of CRT glass. It is present in all types of glasses in both monochrome and color CRT ranging from 50 to $66 \%$ of total weight. Barium oxide is also present in panel and funnel glass, while lead oxide is present in neck glass of both monochrome and color CRT and in funnel glass in color CRT, in addition to less quantities of various other oxides and heavy metals [59]. Chemical structure of funnel and panel glass in both monochrome and color CRT is presented in Table $2[49,60]$. It can be noticed that funnel glass and panel glass in monochrome CRT have almost the same chemical composition, whereas the case is different in color CRT, especially in lead, barium, and strontium content.

Table 2. Chemical content of monochrome and color CRT glasses, data from $[49,60]$.

\begin{tabular}{ccccc}
\hline Oxide & \multicolumn{2}{c}{ Black \& White CRT Glasses } & \multicolumn{2}{c}{ Color CRT Glasses } \\
\hline & Panel Glass & Funnel Glass & Panel Glass & Funnel Glass \\
$\mathrm{SiO}_{2}$ & 66.05 & 65.49 & 61.23 & 56.72 \\
$\mathrm{Al}_{2} \mathrm{O}_{3}$ & 4.36 & 4.38 & 2.56 & 3.42 \\
$\mathrm{Na}_{2} \mathrm{O}$ & 7.63 & 7.05 & 8.27 & 6.99 \\
$\mathrm{~K}_{2} \mathrm{O}$ & 6.65 & 5.72 & 5.56 & 5.37 \\
$\mathrm{CaO}$ & 0.00 & 0.00 & 1.13 & 3.12 \\
$\mathrm{MgO}$ & 0.01 & 0.00 & 0.76 & 2.02 \\
$\mathrm{BaO}$ & 11.38 & 11.20 & 10.03 & 4.03 \\
$\mathrm{SrO}$ & 0.99 & 0.94 & 8.84 & 1.99 \\
$\mathrm{Fe} \mathrm{O}_{3}$ & 0.44 & 0.44 & 0.10 & 0.11 \\
$\mathrm{CoO}$ & 0.01 & 0.01 & 0.02 & 0.00 \\
$\mathrm{TiO}$ & 0.03 & 0.35 & 0.19 \\
$\mathrm{ZrO}$ & 0.13 & 0.01 & 0.91 & 0.24 \\
$\mathrm{ZnO}$ & 0.07 & 0.00 & 0.18 & 0.22 \\
$\mathrm{PbO}$ & 0.00 & 0.00 & 0.02 & 15.58 \\
$\mathrm{NiO}$ & 0.03 & 0.03 & 0.03 & 0.02 \\
$\mathrm{P}_{2} \mathrm{O}_{5}$ & 0.04 & 0.00 & 0.00 & - \\
$\mathrm{Others}_{\mathrm{Total}}$ & 0.00 & 3.56 & - & 100 \\
\hline
\end{tabular}


Figure 4 presents the content of silica and lead in CRT funnel glass used in cementbased materials from selected literature [36,52,61-65]. It was found that usually, CRT funnel glass used in literature contained more lead (18-35\%) than that expected according to earlier records $(15 \%)[49,60]$. This variation might be due to CRT monitors originating from different manufacturers. The silica content, conversely, was as anticipated.

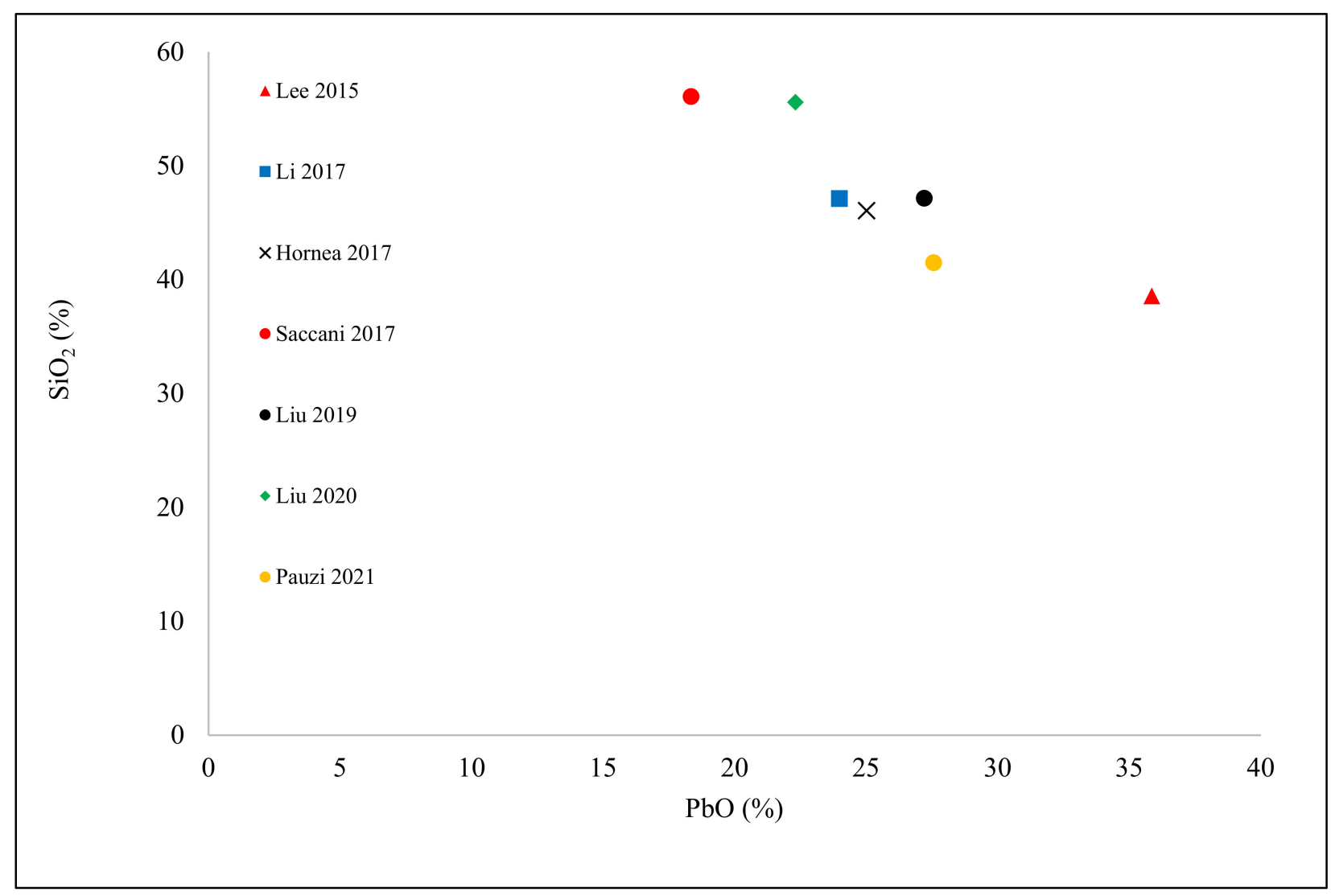

Figure 4. $\mathrm{SiO}_{2}$ and $\mathrm{PbO}$ content in CRT funnel glass, data from [36,52,61-65].

\section{Consistency}

\subsection{Mortar}

Hui and Sun [66] replaced sand with up to $100 \%$ treated CRT glass and non-treated CRT glass in the production of mortar. They reported that using CRT glass in mortar results in a noticeable increase (over 165\%) in slump flow compared with mortar made with river sand. The presence of non-treated CRT glass produced higher slump flow compared to the treated CRT. Additionally, using CRT glass causes a decline in the slump flow loss rate of mortar compared that of river sand.

Ling and Poon [67] used five different replacement levels (by volume): 0, 25, 50, 75 and $100 \%$ of sand with CRT glass in mortar. The flow spread diameter gradually increased from 120 to $190 \mathrm{~mm}$ when sand was fully replaced with CRT glass. This is explained by the impermeable and smooth surface of CRT glass [68]. The same authors confirmed these results in other studies $[69,70]$, where they also showed that the consistency of mortar mixtures decreased with the decrease of fineness of CRT glass.

Furthermore, Zhao et al. [71] replaced sand with CRT glass at replacement levels 0, 25, 50 , and $75 \%$ in mortar. They found that the incorporation of non-treated CRT funnel glass improved the slump flow, ranging from $120 \mathrm{~mm}$ to $220 \mathrm{~mm}$. Additionally, slump flow loss rate was reduced as the replacement level of CRT glass increased. 
Conversely, Choi et al. [72] used different water binder ratios in mortar and replaced sand with $0,25,50,75$, and 100\% CRT glass. The slump flow value increased as the substitution level of CRT glass increased.

Sua-iam and Makul [73] tested self-compacting mortar using 0, 20, and 40\% CRT glass as a replacement of sand and with the addition of different amounts of limestone as a SCM. The slump slightly decreased as CRT glass content increased, possibly due to lower fineness modulus of CRT glass when compared with the sand used in the study [74,75]. Table 3 summarizes the impact of CRT glass on slump of mortar from selected literature $[66,67,69,71]$.

Table 3. Slump value of mortar containing CRT glass, data from $[66,67,69,71]$.

\begin{tabular}{|c|c|c|c|c|c|}
\hline Authors & W/B ${ }^{1}$ & Replacement Level (\%) & $\mathrm{SCM}^{2}$ & Treatment & Slump (\% of Control Mix) \\
\hline \multirow{4}{*}{ Hui and Sun, 2011 [66] } & 0.45 & 100 & $\mathrm{FA}^{3}$ & Yes & 165 \\
\hline & 0.45 & 100 & FA & No & 173 \\
\hline & 0.45 & 100 & GGBFS ${ }^{4}$ & Yes & 153 \\
\hline & 0.45 & 100 & GGBFS & No & 162 \\
\hline \multirow{4}{*}{ Ling and Poon, 2011 [67] } & 0.45 & 25 & FA & Yes & 118 \\
\hline & 0.45 & 50 & FA & Yes & 133 \\
\hline & 0.45 & 75 & FA & Yes & 148 \\
\hline & 0.45 & 100 & FA & Yes & 158 \\
\hline \multirow{4}{*}{ Ling and Poon, 2012 [69] } & 0.45 & 25 & FA & Yes & 119 \\
\hline & 0.45 & 50 & FA & Yes & 133 \\
\hline & 0.45 & 75 & FA & Yes & 146 \\
\hline & 0.45 & 100 & FA & Yes & 158 \\
\hline \multirow{6}{*}{ Zhao et al., 2013 [71] } & 0.45 & 25 & FA & No & 138 \\
\hline & 0.45 & 50 & FA & No & 160 \\
\hline & 0.45 & 75 & FA & No & 184 \\
\hline & 0.45 & 25 & GGBFS & No & 118 \\
\hline & 0.45 & 50 & GGBFS & No & 128 \\
\hline & 0.45 & 75 & GGBFS & No & 165 \\
\hline
\end{tabular}

${ }^{1}$ Water to binder ratio. ${ }^{2}$ Supplementary cementitious materials. ${ }^{3}$ Fly ash. ${ }^{4}$ Ground granulated blast furnace slag.

\subsection{Concrete}

Zhao et al. [76] replaced sand with treated CRT glass at substitution levels of 0, 25, 50 and $75 \%$ by volume. The authors reported that as the volume of replacement level of treated CRT glass increased from 0 to $75 \%$, the initial slump increased from $40 \mathrm{~mm}$ to $135 \mathrm{~mm}$. Additionally, by visual inspection, it is seen that higher replacement levels of CRT glass resulted in more consistent and homogenous concrete mixtures, with less bleeding and segregation. Kim et al. [77] replaced sand with CRT glass at 0, 50, 100\% replacement levels (by volume) using different water to binder ratios. There was an increase in the slump flow due to the presence of CRT glass regardless of water to binder ratios. Moreover, Ouldkhaoua et al. [78] produced self-compacting concrete by replacing sand with CRT glass at $0,10,20,30,40,50 \%$ substitution levels (by volume) incorporating different amounts of metakaolin as SCM. The slump increased with the increase of CRT glass, reaching its maximum at $50 \%$ replacement level. Liu et al. [62] replaced sand with up to $100 \%$ CRT glass in order to produce ultra-high performance concrete and it was found that the consistency of concrete improved when CRT glass is used. Additionally, Bawab et al. [79] replaced sand with CRT glass at $0,10,20$, and $30 \%$ replacement levels by volume in concrete. They concluded that lower dosage of water reducer was required as the amount of CRT increased indicating that the inclusion of CRT in concrete improves the consistency.

Romero et al. [80] replaced sand with up to $30 \%$ CRT glass by volume and observed that CRT glass resulted in a decrease in concrete slump flow. This reduction was explained by the angular and edged grain shape property of CRT glass [81]. Similarly, Wang et al. [82] replaced up to $50 \%$ of sand with non-treated and surface treated CRT glass waste and found that the inclusion of CRT glass waste reduced the slump. Higher friction due to sharp and 
unrounded glass was associated with this decrease in the slump [83,84]. Surface-treated CRT glass waste caused a very slight decrease in slump which may be due to surface treatment that could have dissolved part of sharp edges in glass particles thus improving fluidity. Furthermore, Iniaghe and Adie [85] replaced sand with 0, 10, 15, 20, and 25\% CRT glass by weight and a drop in consistency was noticed when CRT glass was present in the concrete mixture. This was possibly caused by the lower fineness modulus of CRT glass used in this study comparing to sand used. Table 4 shows the effect of CRT glass on slump values of concrete from selected literature $[62,76,77,82]$.

Table 4. Slump value of concrete containing CRT glass, data from $[62,76,77,82]$.

\begin{tabular}{|c|c|c|c|c|c|}
\hline Authors & W/B ${ }^{1}$ & Replacement Level (\%) & $\mathrm{SCM}^{2}$ & Treatment & Slump (\% of Control Mix) \\
\hline \multirow{3}{*}{ Zhao et al., 2013 [76] } & 0.48 & 25 & $\mathrm{FA}^{3}$ & Yes & 213 \\
\hline & 0.48 & 50 & FA & Yes & 300 \\
\hline & 0.48 & 75 & FA & Yes & 338 \\
\hline \multirow{6}{*}{ Kim et al., 2018 [77] } & 0.35 & 50 & - & No & 195 \\
\hline & 0.35 & 100 & - & No & 286 \\
\hline & 0.45 & 50 & - & No & 155 \\
\hline & 0.45 & 100 & - & No & 215 \\
\hline & 0.55 & 50 & - & No & 138 \\
\hline & 0.55 & 100 & - & No & 146 \\
\hline \multirow{4}{*}{ Wang et al., 2019 [82] } & 0.40 & 5 & FA & No & 87 \\
\hline & 0.40 & 15 & FA & No & 62 \\
\hline & 0.40 & 25 & FA & No & 46 \\
\hline & 0.40 & 25 & FA & Yes & 95 \\
\hline \multirow{4}{*}{ Liu et al., 2020 [62] } & 0.18 & 25 & $\mathrm{SF}^{4}$ & No & 105 \\
\hline & 0.18 & 50 & $\mathrm{SF}$ & No & 107 \\
\hline & 0.18 & 75 & SF & No & 108 \\
\hline & 0.18 & 100 & SF & No & 106 \\
\hline
\end{tabular}

${ }^{1}$ Water to binder ratio. ${ }^{2}$ Supplementary cementitious materials. ${ }^{3}$ Fly ash. ${ }^{4}$ Silica Fume.

As it is evident, most studies indicate a better consistency when using CRT glass. This is mainly due to the soft surface and low permeability of CRT glass. However, other characteristics may reduce the flow of mortar or concrete, such as sharp edges and harsh texture [19]. Additionally, fineness modulus of CRT glass used in each study had an important impact on slump. Other factors affecting the consistency include treatment method of CRT glass, in addition to the method of crushing which determines the size, shape, and texture of CRT glass that will be used later in mortar or concrete mixes. It is worth mentioning that the increase in consistency due to CRT glass was more obvious in mortar than concrete.

\section{Density}

Zhao et al. [71] found that increasing the CRT glass replacement from 0 to $75 \%$ caused a rise in wet density of mortar from $2176 \mathrm{~kg} / \mathrm{m}^{3}$ to $2408 \mathrm{~kg} / \mathrm{m}^{3}$. This is expected since CRT glass has a higher density $\left(3042 \mathrm{~kg} / \mathrm{m}^{3}\right)$ than river sand $\left(2620 \mathrm{~kg} / \mathrm{m}^{3}\right)$. These authors reported similar results in another study [76], where the wet density of concrete increased from 2914 to $2992 \mathrm{~kg} / \mathrm{m}^{3}$ after replacing 75\% of sand with CRT glass by volume. Additionally Romero et al. [80] noticed an increase in wet density of concrete when replacing limestone sand with CRT glass. Zhao and Poon [86] replaced sand in mortar by both treated and non-treated CRT glass at substitution levels $0,25,50$, and $75 \%$. The wet density increased with the increase of substitution level. Yet, at the same substitution level, non-treated CRT glass mortar had a higher density than treated CRT glass mortar. This is better illustrated in Figure 5 [86]. 


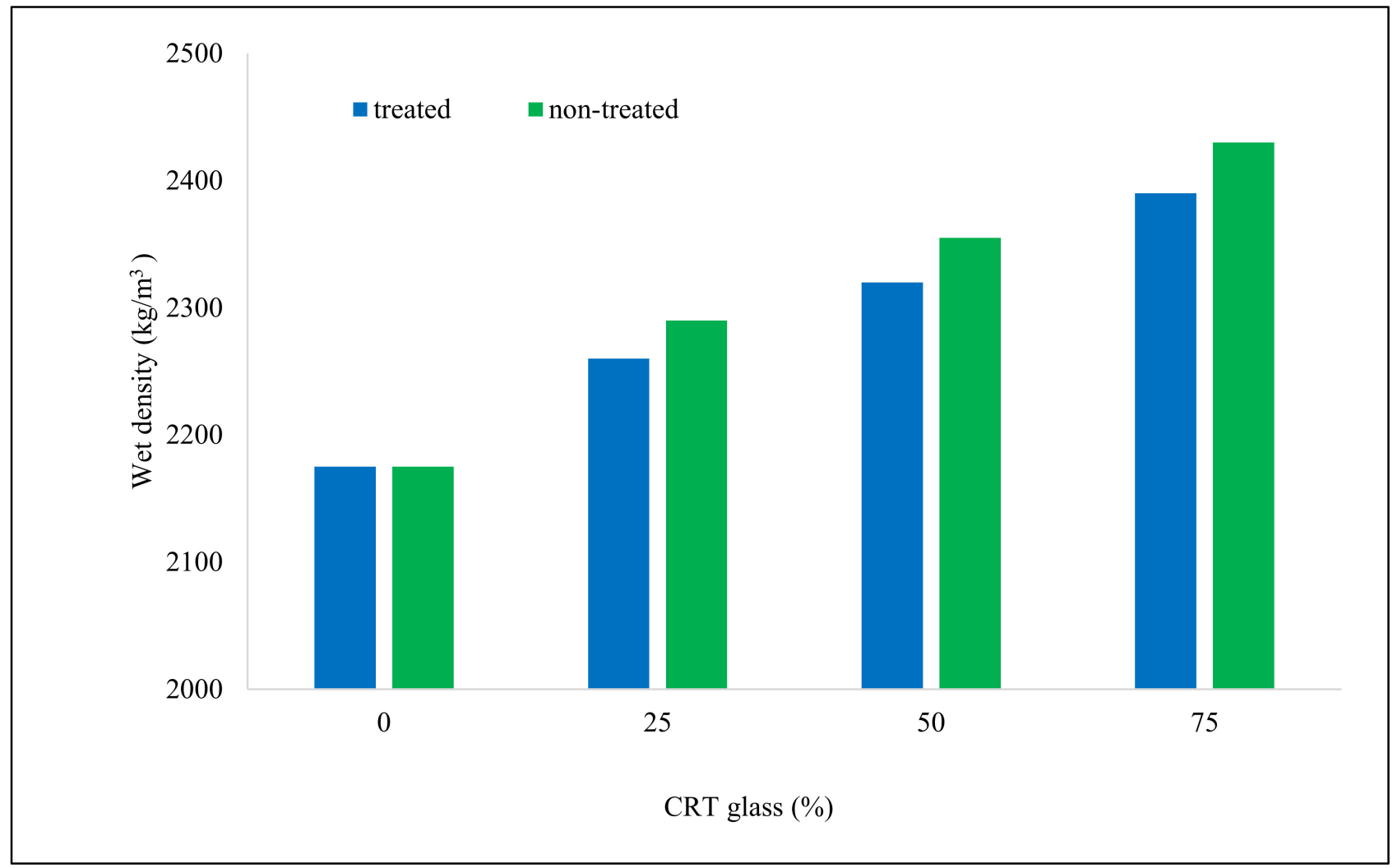

Figure 5. Wet density of mortar containing CRT glass at different replacement levels, redrawn from [86].

Ling et al. [87] replaced sand with beverage glass, non-treated CRT glass, and treated CRT glass at $0,25,50,75,100 \%$ by volume. Hardened density of mortar increased by $11.2 \%$ for treated CRT funnel glass and $14.6 \%$ for non-treated CRT glass when comparing with the control concrete mixture at replacement level of 100\%. Choi et al. [72] observed an increase by around $17 \%$ for CRT glass at 100\% replacement level regardless of the water-binder ratio and mineral admixture used. Yildirim [88] substituted CRT glass for sand at replacement levels $0,5,10,15$, and $20 \%$ by weight. The author indicated that the density of hardened concrete increased up to $15 \%$ then decreased when CRT glass content is $20 \%$, finding a similar trend in an earlier study [89]. Song et al. [90] replaced sand with CRT glass at replacement levels of $0,20,40,60,80,100 \%$ by weight, and different particle size groups $(4.75,2.36,1.18,0.60 \mathrm{~mm})$ for $100 \%$ replacement level. The hardened density of concrete increased gradually as replacement levels increased, from $2303 \mathrm{~kg} / \mathrm{m}^{3}$ for control mix to $2423 \mathrm{~kg} / \mathrm{m}^{3}$. At $100 \%$ replacement level, hardened density decreased as the grain size of CRT glass reduced (Figure 6) [90].

As is expected, including CRT glass in concrete or mortar led to an increase in the fresh and hardened density. This is mainly because of the higher density of treated and non-treated CRT glass compared to that of sand. While higher density is not preferred in general for structural concrete, high density concrete is appropriate for some engineering applications, such as radiation shielding [91]. 


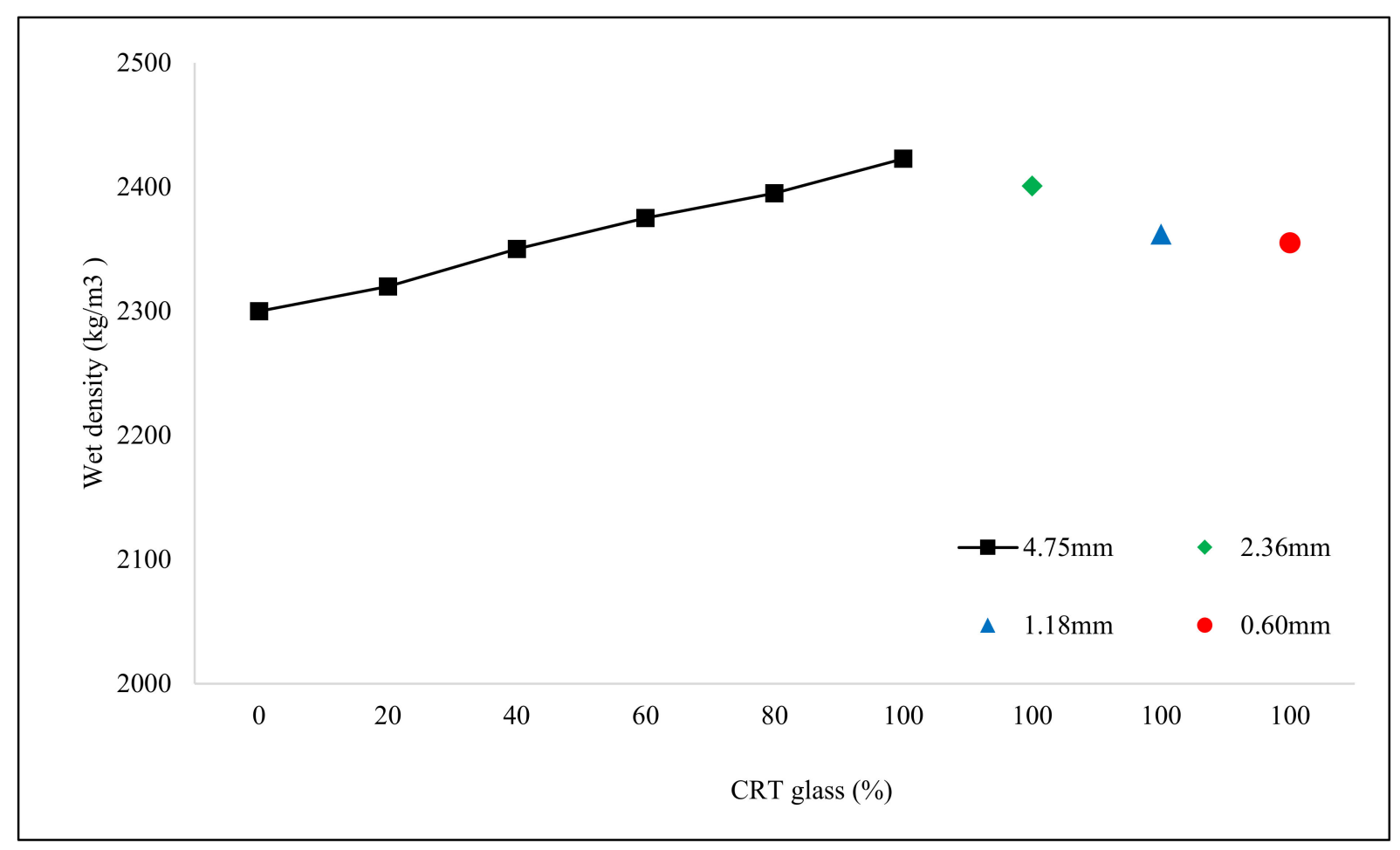

Figure 6. Hardened density of concrete containing CRT glass at different replacement levels and different maximum particle size, redrawn from [90].

\section{Strength}

\subsection{Mortar}

Hui and Sun [66] indicated that mortar with treated or non-treated CRT glass waste had a compressive strength higher than that of mortar with river sand. For example, the compressive strength of mortar with CRT glass without treatment is $41 \%$ higher than that of mortar with sand at 28 days. This increase was justified by the probable improvement of particle packing [92]. It was also found in this study that CRT glass enhances flexural strength of mortar. Additionally, Zhao et al. [71] found that the compressive and flexural strengths of mortar increased as more CRT glass was incorporated into the mixture. In fact, this increase reached $35 \%$ when $75 \%$ of sand was replaced with CRT funnel glass owing to the accelerated cement hydration due to the filler effect of CRT glass [81]. Walczak et al. [93] noted an increase in the 28-days compressive strength from 17.1 to $19.8 \mathrm{MPa}$ and an increase in flexural strength from 3.8 to $4.4 \mathrm{MPa}$ when the sand was fully replaced with CRT glass. Similar results were obtained by Zhao and Poon [86]. When comparing the effect of non-treated CRT glass and treated CRT glass, it was observed that non-treated CRT glass mortar yielded more strength, especially at longer curing periods [86]. For example, at 75\% replacement level, the flexural strength of mortar using non-treated CRT glass at 28 days curing period increased by more than $7 \%$ in comparison to treated CRT glass counterpart. This value increases to $12.6 \%$ at 90 days curing period, which is explained by the formation of more calcium silicate hydrates (C-S-H) at late curing periods due to the presence of $\mathrm{SiO}_{2}$ in the CRT glass [94]. The compressive strength also increased when replacing sand with CRT glass.

Ling and Poon [67] found that increasing CRT glass replacement level in mortar led to gradual decrease in both compressive and flexural strength with the increase of CRT glass content. The authors argued that the smooth surface of the CRT glass resulted in a weaker bond with the cement paste $[81,95,96]$. However, this decrease was more noticeable at early curing ages. At later curing ages and due to the pozzolanic reaction of CRT glass with calcium hydroxide, there was less decrease in strength [97]. The same authors found analogous results in other studies, where treated and non-treated CRT glass 
caused a reduction in the compressive and flexural strength of mortar $[70,87,98]$. Further, Choi et al. [72] observed that the compressive and flexural strength of mortar decreases with the inclusion of CRT glass, regardless of the water-binder ratio and the mineral admixture used, possibly due to less adhesion between glass and cement [99-101]. Liu et al. [102] replaced sand with up to $100 \%$ (by weight) CRT glass with maximum particle size of $2.5 \mathrm{~mm}$ They concluded that the compressive and flexural strengths of cement mortars decreased as CRT glass content increased, particularly between $0 \%$ and $60 \%$, whereas there is little change in strength at replacement levels above $60 \%$. Ouldkhaoua et al. [103] produced self-compacting mortar using 0 to $50 \%$ treated CRT glass as replacement of sand and different amounts of metakaolin as SCM. The compressive and flexural strength gradually decreased with the increase of CRT glass content. Similar to other studies, the authors explained that this decrease was owed to the lower adhesion between the CRT glass and cement caused by smooth surface of the CRT glass $[67,73]$. Table 5 shows compressive and flexural strength at 28 days for mortar from selected literature [66,67,71,98,102].

Table 5. Compressive and flexural strength at 28 days for mortar containing CRT glass, data from $[66,67,71,98,102]$.

\begin{tabular}{|c|c|c|c|c|c|c|}
\hline Authors & W/B ${ }^{1}$ & Replacement Level (\%) & $\mathrm{SCM}^{2}$ & Treatment & $\begin{array}{l}\text { Compressive Strength } \\
\text { (\% of Control Mix) }\end{array}$ & $\begin{array}{l}\text { Flexural Strength } \\
\text { (\% of Control Mix) }\end{array}$ \\
\hline \multirow{4}{*}{$\begin{array}{l}\text { Hui and Sun, } \\
2011[66]\end{array}$} & 0.45 & 100 & $\mathrm{FA}^{3}$ & Yes & 136 & 105 \\
\hline & 0.45 & 100 & FA & No & 141 & 107 \\
\hline & 0.45 & 100 & GGBFS 4 & Yes & 137 & 102 \\
\hline & 0.45 & 100 & GGBFS & No & 155 & 107 \\
\hline \multirow{4}{*}{$\begin{array}{l}\text { Ling and Poon, } \\
2011 \text { [67] }\end{array}$} & 0.45 & 25 & FA & Yes & 99 & 98 \\
\hline & 0.45 & 50 & FA & Yes & 94 & 89 \\
\hline & 0.45 & 75 & FA & Yes & 93 & 77 \\
\hline & 0.45 & 100 & FA & Yes & 79 & 61 \\
\hline \multirow{4}{*}{$\begin{array}{l}\text { Ling and Poon, } \\
2012 \text { [98] }\end{array}$} & 0.45 & 50 & FA & No & 93 & 91 \\
\hline & 0.45 & 100 & FA & No & 80 & 72 \\
\hline & 0.45 & 50 & FA & Yes & 101 & 92 \\
\hline & 0.45 & 100 & FA & Yes & 83 & 65 \\
\hline \multirow{6}{*}{$\begin{array}{l}\text { Zhao et al., } \\
2013 \text { [71] }\end{array}$} & 0.45 & 25 & FA & No & 114 & 104 \\
\hline & 0.45 & 50 & FA & No & 122 & 109 \\
\hline & 0.45 & 75 & FA & No & 131 & 113 \\
\hline & 0.45 & 25 & GGBFS & No & 104 & 106 \\
\hline & 0.45 & 50 & GGBFS & No & 109 & 109 \\
\hline & 0.45 & 75 & GGBFS & No & 113 & 115 \\
\hline \multirow{5}{*}{$\begin{array}{l}\text { Liu et al., } \\
2018 \text { [102] }\end{array}$} & 0.51 & 20 & FA & No & 96 & 87 \\
\hline & 0.51 & 40 & FA & No & 92 & 85 \\
\hline & 0.51 & 60 & FA & No & 86 & 73 \\
\hline & 0.51 & 80 & FA & No & 88 & 78 \\
\hline & 0.51 & 100 & FA & No & 87 & 74 \\
\hline
\end{tabular}

${ }^{1}$ Water to binder ratio. ${ }^{2}$ Supplementary cementitious materials. ${ }^{3}$ Fly ash. ${ }^{4}$ Ground granulated blast furnace slag.

\subsection{Concrete}

Ling and Poon [104] replaced sand with up to $100 \%$ treated and non-treated CRT glass by volume and found that using CRT glass reduced the compressive and splitting tensile strength during the early ages of curing. However, it was noticed in another study that the reduction was partially overcome after a longer curing period, possibly due to cement hydration caused by lead in the CRT glass [76]. Ling and Poon [105] replaced sand with up to $100 \%$ treated CRT glass and found that the concrete compressive strength decreased with the increase in CRT glass content at both normal temperature and elevated temperatures of curing. Wang et al. [82] also indicated that including CRT glass in concrete caused a reduction in the compressive strength and flexural strength attributed to the less effective bonding area between CRT glass and cement due to its smooth surface [106]. Furthermore, Song et al. [90] reported reductions of 16.8 and $10.2 \%$ in compressive and splitting tensile strengths at 28 days when sand was fully replaced with CRT glass. However, the decreased particle size of CRT glass contributed to a higher 
compressive and tensile strength. Liu et al. [107] replaced sand by with to $60 \%$ treated CRT glass with maximum particle size of $3 \mathrm{~mm}$. The compressive strength of concrete decreased with the increase in substitution levels, reaching a $12.7 \%$ reduction for $60 \%$ replacement level at 28 days. Zhao et al. [76], Wang et al. [82], and Ouldkhaoua et al. [78] found similar results. The reduction in compressive and flexural strength was reported to be due to the smooth surface of CRT glass particles, thus affecting the bond with the cement paste [106].

On the other hand, Romero et al. [80] noticed an increase in compressive strength of concrete when using CRT glass. Iniaghe and Adie [85] also observed an increase in compressive strength of concrete from 15.6 MPa for control mix to $21.1 \mathrm{MPa}$ for $25 \%$ replacement level of CRT glass. Results of the effect of CRT glass on 28 days compressive strength of concrete from selected literature are shown in Table 6 [82,104,107].

Table 6. Compressive and flexural strength at 28 days for concrete containing CRT glass, data from [82,104,107].

\begin{tabular}{|c|c|c|c|c|c|c|}
\hline Authors & $\mathbf{W} / \mathbf{B}^{1}$ & Replacement Level (\%) & $\mathrm{SCM}^{2}$ & Treatment & $\begin{array}{l}\text { Compressive Strength } \\
\text { (\% of Control Mix) }\end{array}$ & $\begin{array}{l}\text { Flexural Strength } \\
\text { (\% of Control Mix) }\end{array}$ \\
\hline \multirow{8}{*}{$\begin{array}{l}\text { Ling and Poon, } \\
2012 \text { [104] }\end{array}$} & 0.48 & 25 & $\mathrm{FA}^{3}$ & Yes & 90 & $\mathrm{~N} / \mathrm{A}$ \\
\hline & 0.48 & 50 & FA & Yes & 90 & $\mathrm{~N} / \mathrm{A}$ \\
\hline & 0.48 & 75 & FA & Yes & 91 & $\mathrm{~N} / \mathrm{A}$ \\
\hline & 0.48 & 100 & FA & Yes & 83 & $\mathrm{~N} / \mathrm{A}$ \\
\hline & 0.48 & 25 & FA & No & 95 & $\mathrm{~N} / \mathrm{A}$ \\
\hline & 0.48 & 50 & FA & No & 89 & $\mathrm{~N} / \mathrm{A}$ \\
\hline & 0.48 & 75 & FA & No & 89 & $\mathrm{~N} / \mathrm{A}$ \\
\hline & 0.48 & 100 & FA & No & 86 & $\mathrm{~N} / \mathrm{A}$ \\
\hline \multirow{3}{*}{$\begin{array}{l}\text { Liu et al., } \\
2019 \text { [107] }\end{array}$} & 0.45 & 20 & FA & No & 90 & $\mathrm{~N} / \mathrm{A}$ \\
\hline & 0.45 & 40 & FA & No & 89 & $\mathrm{~N} / \mathrm{A}$ \\
\hline & 0.45 & 60 & FA & No & 87 & $\mathrm{~N} / \mathrm{A}$ \\
\hline \multirow{4}{*}{$\begin{array}{l}\text { Wang et al., } \\
2019 \text { [82] }\end{array}$} & 0.4 & 5 & FA & No & 89 & 94 \\
\hline & 0.4 & 15 & FA & No & 86 & 92 \\
\hline & 0.4 & 25 & FA & No & 81 & 86 \\
\hline & 0.4 & 25 & FA & Yes & 85 & 116 \\
\hline
\end{tabular}

${ }^{1}$ Water to binder ratio. ${ }^{2}$ Supplementary cementitious materials. ${ }^{3}$ Fly ash.

Based on the majority of reported results, it can be deduced that CRT glass reduced the compressive, flexural, and splitting tensile strength of mortar and concrete. In general, the smooth surface of CRT glass causes a weaker bonding with the cement paste in the cementitious matrix. The use of some mineral admixtures, such as metakaolin, could compensate for the loss of strength. In addition, the high silica content of CRT glass causes a pozzolanic reaction at late curing periods which enhances the long-term strength, especially when the CRT glass particles have a fineness that facilitate such reactions. This property of CRT glass concrete could be beneficial, thus allowing the use of CRT glass waste in some engineering applications.

\section{Modulus of Elasticity}

Hui and Sun [66] reported that the modulus of elasticity of mortar at 28 days increased from 7.89 GPa for the control mixture to 12.47 and 10.26 GPa for non-treated and treated CRT glass representing 58\% and 30\% increase, respectively. Zhao et al. [71] noticed a gradual increase in the modulus of elasticity of mortar with increasing amounts of CRT glass. The authors found a high correlation between modulus of elasticity and compressive strength. Zhao and Poon [86] observed an increase of modulus of elasticity with the increase of both non-treated and treated CRT glass in mortar. At the same replacement level, the non-treated CRT glass had slightly higher values than treated CRT glass. Ling and poon [104] reported that using CRT glass caused an increase in modulus of elasticity at some replacement levels and a decrease at other replacement level. Results of modulus of elasticity varied between 16.4 GPa and 20.9 GPa. Bawab et al. [108] partially replaced sand with CRT glass and reported an increase in modulus of elasticity at $10 \%$ replacement level then a decrease at further replacement levels. This was noticeable in the behavior of 
reinforced concrete beams, where higher modulus of elasticity resulted in less deformation at the same load.

In contrast, Zhao et al. [76] found that including CRT glass as fine aggregate caused a slight reduction in modulus of elasticity of about 7 when $75 \%$ of sand was replaced with CRT glass in concrete. However, the reduction in compressive strength was much higher at the same replacement level. A similar result was found by Liu et al. [109] when sand was partially replaced with 30,60,100\% CRT glass by volume. It was found that the static modulus of elasticity of concrete decreased from 31.59 to $26.32 \mathrm{GPa}$ as the replacement increased from 0 to $100 \%$. The authors observed that dynamic static modulus of elasticity also decreased when using more CRT glass content. Yildirim [88] reported an increase in the modulus of elasticity modulus at 5 and 10\% CRT replacement while Song et al. [90] noticed that the modulus of elasticity of concrete with 100\% CRT glass replacement decreased by $13.2 \%$ when compared with the control mixture. It was revealed that a smaller maximum particle size of CRT glass enhanced the modulus of elasticity. Wang et al. [82] observed a $15.7 \%$ decrease in dynamic modulus of elasticity when replacing $25 \%$ of the sand with non-treated CRT glass. Yet, an increase in dynamic modulus of elasticity was noted between non-treated and surface treated CRT glass at 25\% replacement level.

The findings of the modulus of elasticity from literature $[71,86,104]$ suggest that there are no consistent results concerning the effect of CRT glass on the modulus of elasticity of mortar and concrete. This possibly indicates that changing the type of fine aggregates in cement-based materials has a marginal impact on the corresponding modulus of elasticity.

\section{Drying Shrinkage}

Hui and Sun [66] reported that the shrinkage of mortar increased with the increase of CRT glass content. When applying fly-ash as SCM, the drying shrinkage of mortar including CRT glass at 56 days is below the limit of $0.075 \%$ specified by the Australian Standard AS 3600 [110]. When using slag, the length change approaches this limit. Zhao et al. [71] found similar results where the use of CRT glass caused an increase in shrinkage length change. However, the drying shrinkage of the mortar specimens having CRT glass substitution levels of 50\% and 75\% exceeded the acceptable limit for mortar mixtures. Zhao and Poon [86] noticed that CRT glass increased the drying shrinkage of mortar. Yet, all treated CRT glass mortar mixtures and those incorporating up to 50\% non-treated CRT glass were below the acceptable limit.

On the contrary, Ling and Poon [104] found that using CRT glass reduced the drying shrinkage gradually owing to the low water absorption of glass. The same authors found similar trend in other studies [67,70,87,98,111-113]. Zhao et al. [76] also observed a reduction in shrinkage with increasing amounts of CRT glass in mortar. The authors argued that the dying shrinkage was directly related to compressive strength, and the reduction of drying shrinkage was explained by the lower compressive strength upon the inclusion of the CRT glass [76]. Wang et al. [82] noted that using both treated and non-treated CRT glass led to a reduction in drying shrinkage of concrete. However, treated CRT glass caused more reduction. This reduction was explained by the low water absorption rate of CRT glass $[76,98]$ and the angular shape of CRT particles $[68,71]$.

\section{Water Absorption}

Ling and Poon [112] replaced sand with up to 100\% treated CRT glass in concrete paving blocks and found that using CRT glass in concrete decreases the water absorption. This was expected since the CRT glass has a lower absorption than sand [113]. Kim et al. [77] noticed a reduction in permeability when adding CRT glass to concrete. This was more apparent with higher water binder ratio, where $15 \%$ reduction in absorption was observed at $100 \%$ CRT replacement (Figure 7). Song et al. [90] found similar results, where increasing CRT glass content gradually reduced water absorption. The authors also observed that a smaller maximum particle size of CRT glass led to further decrease in water absorption. Ouldkhaoua et al. [103] also observed that using CRT glass reduced water absorption of 
concrete. Liu et al. [109] reported a decrease in water absorption of concrete from $3.64 \%$ for the control mix to $3.19 \%$ when CRT glass fully replaced the sand. This is conflicting with the findings of other studies [70].

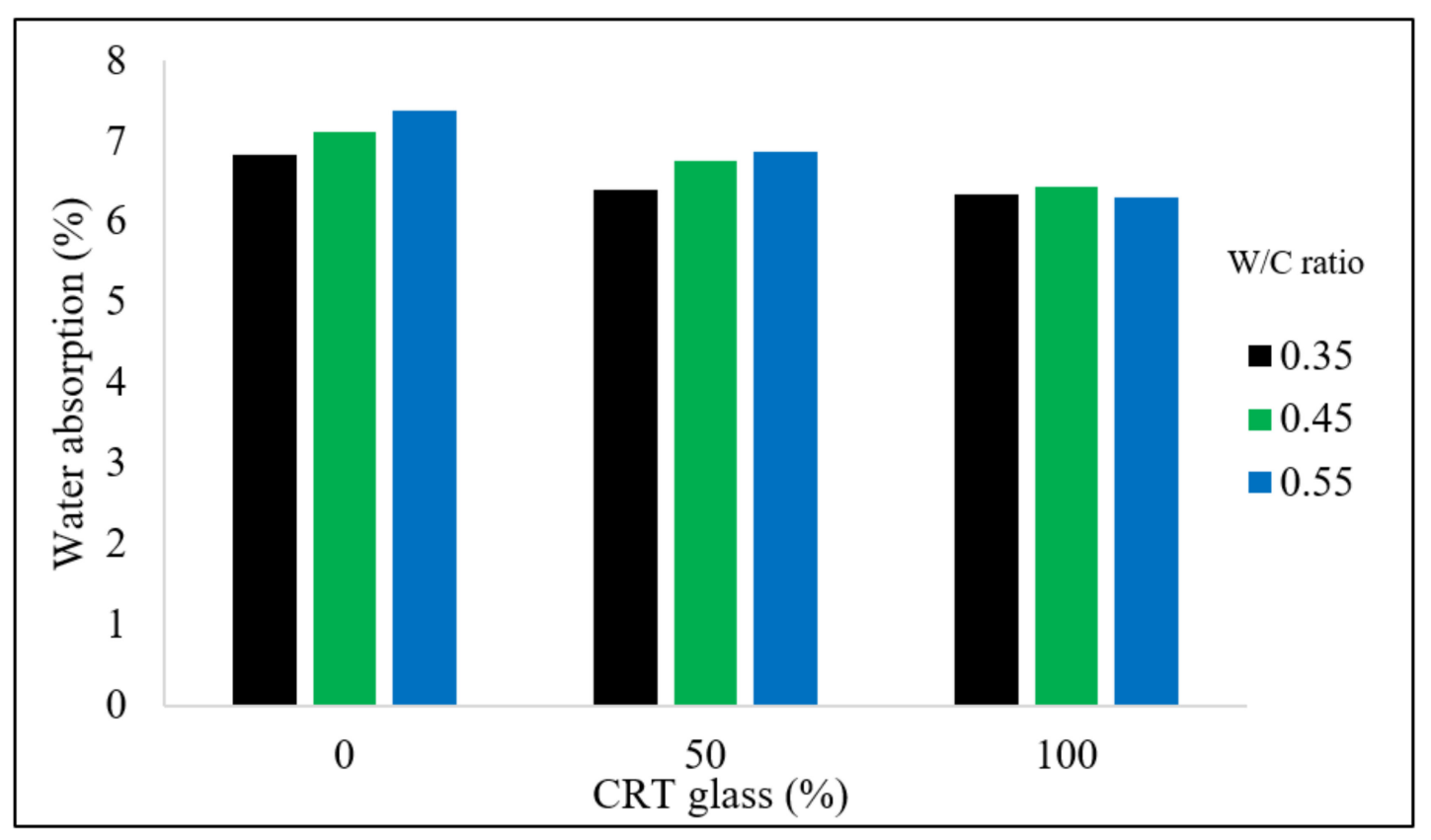

Figure 7. Water absorption ratio at different replacement levels and w/c ratios, redrawn from [77].

Yildirim [88] indicated that the water absorption of concrete decreased from 6.46 to $6.05 \%$ for mixtures made with $0 \%$ and $10 \%$ CRT replacement, respectively. A subsequent increase to $6.97 \%$ was observed at $20 \%$ replacement level. The author suggested that increasing the CRT glass replacement level from 15 to $20 \%$ causes a higher porosity in concrete specimens. A similar explanation, i.e., increase in void content in the cementitious matrix, was given in another study, where the water absorption increased in ultra-high performance concrete from $1.74 \%$ for control mixture to $2.4 \%$ for the mixture sand fully replaced with CRT [62].

In general, the use of CRT glass led to the reduction of the water absorption of cement mortar and concrete. It is suggested that near-zero water absorption of glass is the main reason behind this effect [25]. Yet, the porosity of the cement-based materials must be taken into consideration for further insight on the effect of CRT glass.

\section{Alkali-Silica Reaction (ASR)}

Hui and Sun [66] reported that using CRT glass in mortar caused an increase in expansion due to ASR. The authors observed that there was a negligible increase in expansion after 14 days of exposure in the control mortar mixture, while mortar mixtures containing CRT glass continued to expand. In addition, the authors mentioned that the use of fly ash as SCM led to a decrease in expansion due to ASR [114], where mortar incorporating ground granulated blast furnace slag surpassed the allowed range of $0.1 \%$ at 14 days specified by ASTM C1260 [115].

Similarly, Ling and Poon [67] noted that treated CRT glass increased ASR expansion values. However, the presence of fly ash in concrete mitigated the expansion mainly due to the pozzolanic reaction which has led to a reduction in alkali content $[116,117]$. Zhao et al. [76] confirmed these results, where using treated CRT glass increased ASR but within the allowed limit due to the use of fly ash (Figure 8). Wang et al. [82] found similar results and proved that surface treatment of CRT glass can reduce ASR with or without the presence of pozzolanic materials. These results are in agreement with those of other works [80], where the expansion of all concrete mixtures that used CRT glass exceeded the 
permitted limit due to the absence of fly ash, and the maximum recommended ratio of CRT glass to replace fine aggregates was $10 \%$ by volume. Further, Bursi et al. [118] replaced $25 \%$ sand with CRT glass in mortar. The authors suggested that treating the CRT glass by nitrilotriacetic acid effectively reduced the expansion caused by ASR when compared to mortars containing non-treated CRT glass.

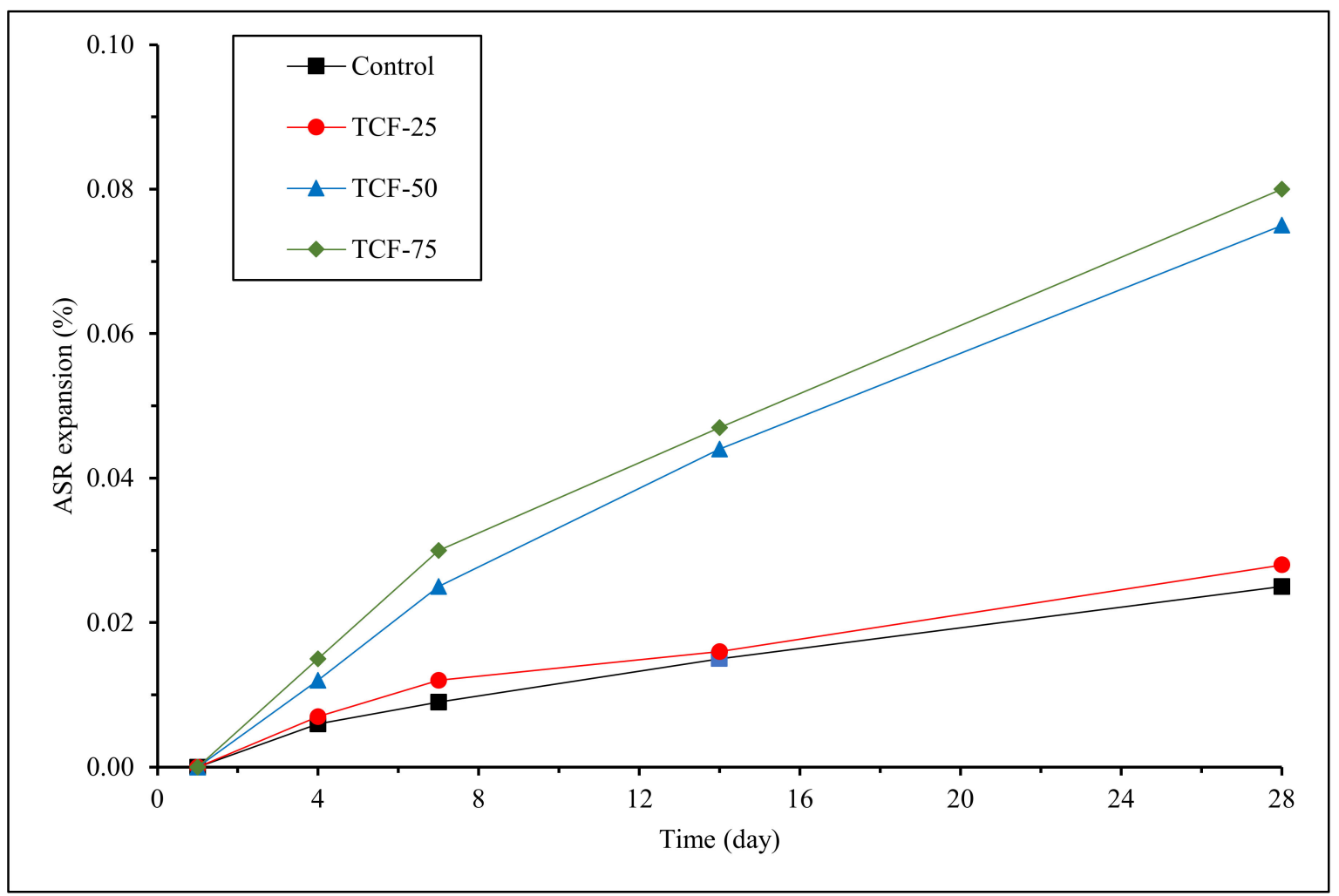

Figure 8. Expansion caused by ASR of mortar containing CRT glass, redrawn from [76].

Yildirim [88] reported that increasing CRT glass content in concrete led to an increased expansion due to ASR. However, the addition of fly ash in concrete containing CRT glass reduced the expansion due to ASR. Ouldkhaoua et al. [78] found that ASR increased as CRT glass content increase, due to the internal cracks caused by higher $\mathrm{SiO}_{2} / \mathrm{CaO}$ ratio [119]. Nevertheless, the authors however that the expansion rates were lower when metakaolin was present in the concrete mixture, where the effect was more noticeable at higher replacement levels.

It can be concluded that CRT glass caused an increased expansion due to ASR. To mitigate this effect, authors recommended the use of pozzolanic SCM, mainly fly ash and metakaolin. Using such SCM generally led to a denser microstructure of the cement-based materials contributing to less expansion due to ASR.

\section{Lead Leaching}

Due to the lead content present in the CRT glass, lead leaching has always posed a concern for its possible applications. Rather than acid treating this glass for the removal of lead, which can be inefficient and costly, lead found in CRT glass can be effectively encapsulated in the cementitious matrix. Kim et al. [120] used several types of biopolymers to encapsulate CRT glass into concrete, resulting in a negligible lead leaching values approaching zero. These results are in agreement with those obtained in other work [121], where biopolymers contributed in the creation of concrete systems having significantly decreased lead leaching. In fact, Romero et al. [80] reported that lead leaching in concrete containing $20 \%$ CRT glass as sand replacement is within the allowable limit if a biopolymer 
was added into the mixture. Another method of encapsulation of lead found in CRT glass was the use of graphene oxide nanoparticles, where graphene oxide counteracted the adverse environmental impacts of waste CRT glass and improved the mechanical properties of cement-based materials using CRT glass as well [122,123].

Ling and Poon [67] reported that lead leaching of mortar using treated CRT glass is below the detection limit of $0.06 \mathrm{ppm}$ according to Toxicity characteristic leaching procedure (TCLP) [124]. It is even lower than that of treated CRT glass before using it in the mortar, which possibly means that alkalinity of cement mortar effectively reduces lead leaching $[125,126]$. Moreover, the use of fly ash further contributed to reducing the lead leaching, through the products formed by the pozzolanic reaction [127]. The same authors [104] assessed the leaching of lead and barium of both treated and non-treated CRT glass in concrete. It was found that all concrete mixtures were under the permitted limit for barium leaching. However, for lead leaching, the concrete mixtures containing 50\% and more non-treated CRT glass exceeded the acceptable limit, while all concrete mixtures with treated CRT glass were below the limit. The authors suggested using a maximum of $25 \%$ replacement of non-treated CRT funnel glass for limiting lead leaching. Similarly, Zhao et al. [71] found that increasing the non-treated CRT glass in mortar resulted in lead leaching above the acceptable limit. However, these leaching values were much less than those of CRT glass alone, indicating that the alkalinity of concrete limited the lead leaching.

Another factor influencing lead leaching in concrete is the method of compaction. Lin and Poon [112] prepared paving blocks using dry-mixing. It was noticed that the control mixture and 50\% treated CRT glass concrete were within the allowable limit. This was a result of manual compaction during casting which led to breakage of glass, and increased lead leaching. To prove this claim, the authors tested concrete mixtures with $100 \%$ CRT glass in two different methods: first by manual and mechanical compaction, second by only mechanical compaction. As expected, concrete mixtures that were compacted mechanically only had an acceptable lead leaching values whereas concrete mixtures that were compacted both manually and mechanically had higher values than the limit.

Lead leaching in cement-based materials might be the main concern when replacing sand with CRT glass. When the alkaline environment of the cementitious matrix is not enough for the immobilization of lead found in CRT glass, a number of methods can be utilized: (a) treating CRT from lead (b) limiting the amount of CRT glass, (c) using fly ash, (d) encapsulation techniques. The mechanisms of these methods are explained in Table 7.

Table 7. Methods of mitigation of lead leaching problem in cement-based materials containing CRT glass.

\begin{tabular}{ccc}
\hline Method & \multicolumn{1}{c}{ Mechanism } & References \\
\hline $\begin{array}{c}\text { Acid treatment of CRT glass } \\
\text { prior to using }\end{array}$ & $\begin{array}{c}\text { CRT glass is treated with diluted acid } \\
\text { (usually nitric acid) to remove lead } \\
\text { oxide. The amount of lead } \\
\text { sharply decreases. }\end{array}$ & {$[67,70,82,86,98,118]$} \\
\hline $\begin{array}{c}\text { Limiting the amount of CRT } \\
\text { glass used }\end{array}$ & $\begin{array}{c}\text { Limit the amount of CRT glass used } \\
\text { in cement-based materials (20-25\%). }\end{array}$ & {$[80,104,111,112]$} \\
\hline Using fly ash & $\begin{array}{c}\text { Fly ash improves the microstructure } \\
\text { of the cement-based materials and } \\
\text { consequently that immobilize lead. }\end{array}$ & {$[36,67,71,86,98]$} \\
\hline $\begin{array}{c}\text { Encapsulation by biopolymers } \\
\text { or graphene oxide }\end{array}$ & $\begin{array}{c}\text { Biopolymers or graphene oxide could } \\
\text { effectively encapsulate the lead found } \\
\text { in CRT glass within the } \\
\text { cementitious matrix. }\end{array}$ & {$[120-123]$} \\
\hline
\end{tabular}

\section{Radiation Shielding}

Ling et al. [87] noticed that radiation shielding properties of mortar were improved with both treated and non-treated CRT glass. This was explained by the dense particles 
that interacted with X-rays reducing the depth of its penetration. Additionally, the authors found that CRT glass further enhanced the radiation shielding properties since they absorb more radiation photons. The same trend was observed in several other studies $[69,98,112]$, where it was also realized that the presence of lead decreases the energy of radiation. Choi et al. [72] found that using CRT glass in mortar improved radiation shielding properties regardless of water to cement ratio and SCMs used. Liu et al. [107] noted that replacing high density magnetite sand with CRT glass enhance the mass attenuation coefficient. However, this replacement has about the same $\gamma$-ray radiation shielding properties. Tian et al. [128] reported that the protective ratio of concrete related to radiation shielding significantly improved when using CRT glass, increasing from $76 \%$ at the control concrete mixture to $83 \%$ when fully replacing the aggregates with CRT glass.

CRT glass effectively improved the radiation shielding properties of concrete when compared to sand. Based on this specific benefit of CRT glass, it could be used in a wide variety of applications related to radiation shielding, such as nuclear power plants and medical facilities [42].

The effectiveness of using CRT glass waste as an alternative to natural heavyweight aggregates in the production of radiation shielding concrete is also associated with less costs. Heavyweight aggregates used in radiation shielding applications are expensive, so there is a demand to find substitutes [129]. Only one study conducted a cost analysis of using CRT glass as a replacement to sand in concrete and found an increase in the material costs [76]. However, the study did not take into consideration the costs of natural heavyweight aggregates, such as hematite, in comparison with CRT glass.

\section{Concluding Remarks and Recommendations}

In the past few decades, the production of concrete has raised significant environmental concerns not only related to $\mathrm{CO}_{2}$ emissions, but also in regard to the depletion of natural resources. It is known that concrete consumes large amounts of natural resources, specifically rocks and sand. The latter, while being largely available and easily extracted, is diminishing. Thus, researchers should be encouraged to search for and test possible replacements of sand in concrete derived from waste materials or industrial byproducts. This paper discusses a possible substitution of sand in concrete known as CRT glass waste.

It was established through this literature review that recycling this type of waste in cement-based materials as a replacement to sand enhances some properties of concrete. Using CRT glass waste in cement-based materials improves its consistency due to its smooth surface and very low water absorption. In some cases, it improves the compressive, flexural, and tensile splitting strength. When used in mortar or concrete, CRT glass waste reduces the drying shrinkage and water absorption properties, where this could be beneficial in many structures such as water retaining structure. For alkali-silica reaction, using SCMs such as fly ash or metakaolin mitigates the risk of alkali silica reaction in concrete containing CRT glass. Lead leaching can be alleviated through various techniques, including acid treatment, encapsulation using biopolymers or graphene oxide, addition of fly ash, or limiting the quantity of CRT glass in the mixture.

Based on the conclusions drawn, further studies should be conducted to extend the knowledge about using CRT glass waste in cement-based materials. These might include the search for techniques to maintain the strength of cement-based materials after replacing sand with CRT glass at full or high replacement levels. In addition, more durability related issues, such as freeze-thaw resistance, carbonation resistance etc. might be assessed for a better insight on the long-term effects of the substitution of sand with CRT glass. Furthermore, the use of CRT glass in structural concrete is not well explored. More studies should be concerned with its effects on the various issues related to structural members such as shear behavior of reinforced concrete beams or creep in reinforced concrete columns. 
Author Contributions: Conceptualization, J.B. and H.E.-H.; methodology, J.B. and L.A.; validation, J.K., H.E.-H. and M.S.K.; formal analysis, J.B.; investigation, J.B.; resources, M.S.K. and L.A.; data curation, J.B.; writing—original draft preparation, J.B.; writing—review and editing, J.K. and H.E.-H.; visualization, J.B.; supervision, J.K.; project administration, J.K. All authors have read and agreed to the published version of the manuscript.

Funding: This research received no external funding.

Institutional Review Board Statement: Not applicable.

Informed Consent Statement: Not applicable.

Data Availability Statement: Data sharing not applicable.

Acknowledgments: The authors would like to acknowledge the administrative and technical support offered by the Faculty of Engineering in Beirut Arab University.

Conflicts of Interest: The authors declare no conflict of interest.

\section{Appendix A. Search Query Used in Scopus Database}

TITLE-ABS-KEY (("cathode-ray tube" OR "cathode-ray tube glass" OR "CRT" OR "CRT glass") AND ("concrete" OR "mortar" OR "cement based material" OR "cementitious material")) AND (LIMIT-TO (PUBSTAGE, "final”)) AND (LIMIT-TO (DOCTYPE, "ar") OR LIMIT-TO (DOCTYPE, “cp”) OR LIMIT-TO (DOCTYPE, “ch”)) AND (LIMIT-TO (LANGUAGE, “English")).

\section{References}

1. Khatib, J.; Baalbaki, O.; Elkordi, A. Metakaolin. Waste and Supplementary Cementitious Materials in Concrete; Woodhead Publishing: Cambridge, UK, 2018; pp. 493-511; ISBN 9780081021569.

2. Menadi, B.; Kenai, S.; Hammat, S.; Khatib, J.M. The Influence of the fineness of mineral additions on strength and drying shrinkage of self-compacting mortars. Key Eng. Mater. 2014, 600, 367-374. [CrossRef]

3. Khatib, J.M.; Mangat, P.S.; Wright, L. Pore size distribution of cement pastes containing fly ash-gypsum blends cured for 7 days. KSCE J. Civ. Eng. 2014, 18, 1091-1096. [CrossRef]

4. Kenai, S.; Menadi, B.; Khatib, J.M. Sustainable construction and low-carbon dioxide concrete: Algeria case. Eng. Sustain. 2014, 167, 45-52. [CrossRef]

5. Khatib, J.M. Effect of initial curing on absorption and pore size distribution of paste and concrete containing slag. KSCE J. Civ. Eng. 2014, 18, 264-272. [CrossRef]

6. Herki, B.M.A.; Khatib, J.M. Structural behaviour of reinforced concrete beams containing a novel lightweight aggregate. Int. J. Struct. Eng. 2016, 7, 1. [CrossRef]

7. Khatib, J.; Jefimiuk, A.; Khatib, S. Flexural behaviour of reinforced concrete beams containing expanded glass as lightweight aggregates. Slovak J. Civ. Eng. 2015, 23, 1-7. [CrossRef]

8. Herki, B.A.; Khatib, J.M. Valorisation of waste expanded polystyrene in concrete using a novel recycling technique. Eur. J. Environ. Civ. Eng. 2017, 21, 1384-1402. [CrossRef]

9. Hamood, A.; Khatib, J.M.; Williams, C. The effectiveness of using Raw Sewage Sludge (RSS) as a water replacement in cement mortar mixes containing unprocessed Fly Ash (u-FA). Constr. Build. Mater. 2017, 147, 27-34. [CrossRef]

10. Khatib, J.; Jahami, A.; Baalbaki, O.; Elkordi, A.; Abdelgader, H. Behavior of reinforced concrete beams containing lightweight aggregate in the tensile zone. BAU J. Sci. Technol. 2020, 1, 3.

11. Alexander, M.; Mindess, S. Aggregates in Concrete; Taylor \& Francis: Abingdon, UK, 2010; ISBN 0203963695.

12. Saviour, M.N. Environmental impact of soil and sand mining: A review. Int. J. Sci. Environ. Technol. 2012, 1, 125-134.

13. Peduzzi, P. Sand, rarer than one thinks. Environ. Dev. 2014, 11, 208-218. [CrossRef]

14. Sonak, S.; Pangam, P.; Sonak, M.; Mayekar, D. Impact of sand mining on local ecology. In Multiple Dimensions of Global Environmental Change; Sonak, S., Ed.; TERI Press: New Delhi, India, 2006; pp. 101-121.

15. Kondolf, G.M. Geomorphic and environmental effects of instream gravel mining. Landsc. Urban Plan. 1994, 28, 225-243. [CrossRef]

16. Gallagher, L.; Peduzzi, P. Sand and Sustainability: Finding New Solutions for Environmental Governance of Global Sand Resources; United Nations Environment Programme: Nairobi, Kenya, 2019.

17. Bawab, J.; Khatib, J.; Kenai, S.; Sonebi, M. A Review on cementitious materials including municipal solid waste incineration bottom ash (MSWI-BA) as aggregates. Buildings 2021, 11, 179. [CrossRef]

18. Kirthika, S.K.; Singh, S.K.; Chourasia, A. Alternative fine aggregates in production of sustainable concrete-A review. J. Clean. Prod. 2020, 268, 122089. [CrossRef]

19. Zheng, K. Recycled Glass Concrete; Woodhead Publishing Ltd.: Cambridge, UK, 2013; Volume 2010, ISBN 9780857094247. 
20. Rashad, A.M. Recycled waste glass as fine aggregate replacement in cementitious materials based on Portland cement. Constr. Build. Mater. 2014, 72, 340-357. [CrossRef]

21. Deshmukh, Y.R.; Pankaj, D.; Ashwinkumar, G.; Sujeet, P.; Prasad, S. Review on experimental investigation of waste glass material as a partial replacement of concrete. J. Adv. Civ. Eng. Manag. 2019, 2, 1.

22. Bignozzi, M.C.; Saccani, A.; Barbieri, L.; Lancellotti, I. Glass waste as supplementary cementing materials: The effects of glass chemical composition. Cem. Concr. Compos. 2015, 55, 45-52. [CrossRef]

23. Eurostat. Waste Statistics in Europe. 2016. Available online: epp.eurostat.ec.europa.eu (accessed on 15 June 2021).

24. Dhir, R.K.; De Brito, J.; Ghataora, G.S.; Lye, C.Q. Production and properties of glass cullet. In Sustainable Construction Materials: Glass Cullet; Elsevier: Amsterdam, The Netherlands, 2018; ISBN 9780081009840.

25. Dhir, R.K.; De Brito, J.; Ghataora, G.S.; Lye, C.Q. Use of glass cullet as a sand component. In Sustainable Construction Materials: Glass Cullet; Elsevier: Amsterdam, The Netherlands, 2018; pp. 167-229; ISBN 9780081009840.

26. Colglazier, W. Sustainable development agenda: 2030. Science 2015, 349, 1048-1050. [CrossRef] [PubMed]

27. Adaway, M.; Wang, Y. Recycled glass as a partial replacement for fine aggregate in structural concrete-Effects on compressive strength. Electron. J. Struct. Eng. 2015, 14, 116-122.

28. De Castro, S.; de Brito, J. Evaluation of the durability of concrete made with crushed glass aggregates. J. Clean. Prod. 2013, 41, 7-14. [CrossRef]

29. Wang, H.-Y.; Zeng, H.; Wu, J.-Y. A study on the macro and micro properties of concrete with LCD glass. Constr. Build. Mater. 2014, 50, 664-670. [CrossRef]

30. Ali, E.E.; Al-Tersawy, S.H. Recycled glass as a partial replacement for fine aggregate in self compacting concrete. Constr. Build. Mater. 2012, 35, 785-791. [CrossRef]

31. Singh, N.; Li, J.; Zeng, X. Global responses for recycling waste CRTs in e-waste. WASTE Manag. 2016, 57, 187-197. [CrossRef]

32. Popovici, A.; Corbu, O.; Popita, G.-E.; Rosu, C.; Proorocu, M.; Sandu, A.V.; Abdullah, M.M.A.B. Modern mortars with electronic waste scraps (glass and plastic). Mater. Plast. 2015, 52, 588-592.

33. Wei, H.; Zhou, A.; Liu, T.; Zou, D.; Jian, H. Dynamic and environmental performance of eco-friendly ultra-high performance concrete containing waste cathode ray tube glass as a substitution of river sand. Resour. Conserv. Recycl. 2020, $162,105021$. [CrossRef]

34. Morrison, C. Reuse of CRT glass as aggregate in concrete. In Proceedings of the Sustainable Waste Management and Recycling: Glass Waste Conference, London, UK, 14-15 September 2004; pp. 91-98.

35. Pauzi, N.N.M.; Jamil, M.; Hamid, R.; Abdin, A.Z.; Zain, M.F.M. Influence of spherical and crushed waste Cathode-Ray Tube (CRT) glass on lead $(\mathrm{Pb})$ leaching and mechanical properties of concrete. J. Build. Eng. 2019, 21, 421-428. [CrossRef]

36. Liu, H.; Shi, J.; Qu, H.; Ding, D. An investigation on physical, mechanical, leaching and radiation shielding behaviors of barite concrete containing recycled cathode ray tube funnel glass aggregate. Constr. Build. Mater. 2019, 201, 818-827. [CrossRef]

37. Hilton, B.; Bawden, K.; Winnebeck, K.; Chandrasiri, C.; Ariyachandra, E.; Peethamparan, S. The functional and environmental performance of mixed cathode ray tubes and recycled glass as partial replacement for cement in concrete. Resour. Conserv. Recycl. 2019, 151, 104451. [CrossRef]

38. Maschio, S.; Tonello, G.; Furlani, E. Recycling glass cullet from waste CRTs for the production of high strength mortars. J. Waste Manag. 2013, 2013, 102519. [CrossRef]

39. Grdić, D.; Ristić, N.; Topličić-Ćurčić, G.; Krstić, D. Potential of usage of self compacting concrete with addition of recycled CRT glass for production of precast concrete elements. Facta Univ. Ser. Archit. Civ. Eng. 2018, 16, 57-66. [CrossRef]

40. Walczak, P.; Małolepszy, J.; Reben, M.; Szymański, P.; Rzepa, K. Utilization of waste glass in autoclaved aerated concrete. Procedia Eng. 2015, 122, 302-309. [CrossRef]

41. Iniaghe, P.O.; Adie, G.U. Management practices for end-of-life cathode ray tube glass: Review of advances in recycling and best available technologies. Waste Manag. Res. J. 2015, 33, 947-961. [CrossRef]

42. Rashad, A.M. Recycled cathode ray tube and liquid crystal display glass as fine aggregate replacement in cementitious materials. Constr. Build. Mater. 2015, 93, 1236-1248. [CrossRef]

43. Yao, Z.; Ling, T.; Sarker, P.K.; Su, W.; Liu, J.; Wu, W. Recycling di ffi cult-to-treat e-waste cathode-ray-tube glass as construction and building materials: A critical review. Renew. Sustain. Energy Rev. 2018, 81, 595-604. [CrossRef]

44. Qi, Y.; Xiao, X.; Lu, Y.; Shu, J.; Wang, J.; Chen, M. Cathode ray tubes glass recycling: A review. Sci. Total Environ. 2019, 650, 2842-2849. [CrossRef]

45. Page, M.J.; McKenzie, J.E.; Bossuyt, P.M.; Boutron, I.; Hoffmann, T.C.; Mulrow, C.D.; Shamseer, L.; Tetzlaff, J.M.; Akl, E.A.; Brennan, S.E.; et al. The PRISMA 2020 statement: An updated guideline for reporting systematic reviews. BMJ 2021, $372, \mathrm{n} 71$. [CrossRef] [PubMed]

46. Rocchetti, L.; Beolchini, F. Environmental burdens in the management of end-of-life cathode ray tubes. Waste Manag. 2014, 34, 468-474. [CrossRef] [PubMed]

47. Singh, N.; Wang, J.; Li, J. Waste cathode rays tube: An assessment of global demand for processing. Procedia Environ. Sci. 2016, 31, 465-474. [CrossRef]

48. Saterlay, A.J.; Wilkins, S.J.; Compton, R.G. Towards greener disposal of waste cathode ray tubes via ultrasonically enhanced lead leaching Green Context. Green Chem. 2001, 3, 149-155. [CrossRef] 
49. Andreola, F.; Barbieri, L.; Corradi, A.; Lancellotti, I. CRT glass state of the art: A case study: Recycling in ceramic glazes. J. Eur. Ceram. Soc. 2007, 27, 1623-1629. [CrossRef]

50. Seeberger, J.; Grandhi, R.; Kim, S.S.; Mase, W.A.; Reponen, T.; Ho, S.; Chen, A. E-Waste management in the United States and public health implications. J. Environ. Health 2016, 79, 207-213.

51. Poon, C.S. Management of CRT glass from discarded computer monitors and TV sets. Waste Manag. 2008, 28, 6389. [CrossRef] [PubMed]

52. Lee, J.-S.; Yoo, H.-M.; Park, S.-W.; Cho, S.-J.; Seo, Y.-C. Recycling of cathode ray tube panel glasses as aggregates of concrete blocks and clay bricks. J. Mater. Cycles Waste Manag. 2016, 18, 552-562. [CrossRef]

53. Singh, N.; Li, J.; Zeng, X. Solutions and challenges in recycling waste cathode-ray tubes. J. Clean. Prod. 2016, 133, 188-200. [CrossRef]

54. Kreng, V.B.; Wang, H.T. The interaction of the market competition between LCD TV and PDP TV. Comput. Ind. Eng. 2009, 57, 1210-1217. [CrossRef]

55. Yamashita, M.; Wannagon, A.; Matsumoto, S.; Akai, T.; Sugita, H.; Imoto, Y.; Komai, T.; Sakanakura, H. Leaching behavior of CRT funnel glass. J. Hazard. Mater. 2010, 184, 58-64. [CrossRef]

56. Lee, C.; Hsi, C. Recycling of Scrap Cathode Ray Tubes. Environ. Sci. Technol. 2002, 36, 69-75. [CrossRef]

57. Herat, S. Recycling of cathode ray tubes (CRTs) in electronic waste. CLEAN Soil Air Water 2008, 36, 19-24. [CrossRef]

58. Meng, W.; Wang, X.; Yuan, W.; Wang, J.; Song, G. The recycling of leaded glass in cathode ray tube (CRT). Procedia Environ. Sci. 2016, 31, 954-960. [CrossRef]

59. Shi, X.; Li, G.; Xu, Q.; He, W.; Liang, H. Research progress on recycling technology of end-of-life CRT glass. Mater. Rev. 2011, $11,1-29$.

60. Andreola, F.; Barbieri, L.; Corradi, A.; Lancellotti, I. Cathode ray tube glass recycling: An example of clean technology. Waste Manag. Res. 2005, 23, 314-321. [CrossRef] [PubMed]

61. Li, J.-S.; Guo, M.-Z.; Xue, Q.; Poon, C.S. Recycling of incinerated sewage sludge ash and cathode ray tube funnel glass in cement mortars. J. Clean. Prod. 2017, 152, 142-149. [CrossRef]

62. Liu, T.; Wei, H.; Zou, D.; Zhou, A.; Jian, H. Utilization of waste cathode ray tube funnel glass for ultra-high performance concrete. J. Clean. Prod. 2020, 249, 119333. [CrossRef]

63. Pauzi, N.N.M.; Hamid, R.; Jamil, M.; Zain, M.F.M. The effect of melted-spherical and crushed CRT funnel glass waste as coarse aggregates on concrete performance. J. Build. Eng. 2021, 35, 102035. [CrossRef]

64. Hornea, L.; Gorea, M.; Har, N. Study of (Pb, Ba)-CRT glass waste behavior as a partial aggregate replacement in cement mortars Stud. Univ. Babes-Bolyai Chem. 2017, 62, 343-356. [CrossRef]

65. Saccani, A.; Bignozzi, M.C.; Barbieri, L.; Lancellotti, I.; Bursi, E. Effect of the chemical composition of different types of recycled glass used as aggregates on the ASR performance of cement mortars. Constr. Build. Mater. 2017, 154, 804-809. [CrossRef]

66. Hui, Z.; Sun, W. Study of properties of mortar containing cathode ray tubes (CRT) glass as replacement for river sand fine aggregate. Constr. Build. Mater. 2011, 25, 4059-4064. [CrossRef]

67. Ling, T.C.; Poon, C.S. Utilization of recycled glass derived from cathode ray tube glass as fine aggregate in cement mortar. J. Hazard. Mater. 2011, 192, 451-456. [CrossRef]

68. Kou, S.C.; Poon, C.S. Properties of self-compacting concrete prepared with recycled glass aggregate. Cem. Concr. Compos. 2009, 31, 107-113. [CrossRef]

69. Ling, T.C.; Poona, C.S. Development of a method for recycling of CRT funnel glass. Environ. Technol. 2012, 33, 2531-2537. [CrossRef]

70. Ling, T.C.; Poon, C.S. Effects of particle size of treated CRT funnel glass on properties of cement mortar. Mater. Struct. Constr. 2013, 46, 25-34. [CrossRef]

71. Zhao, H.; Poon, C.S.; Ling, T.C. Properties of mortar prepared with recycled cathode ray tube funnel glass sand at different mineral admixture. Constr. Build. Mater. 2013, 40, 951-960. [CrossRef]

72. Choi, S.Y.; Choi, Y.S.; Yang, E.I. Effects of heavy weight waste glass recycled as fine aggregate on the mechanical properties of mortar specimens. Ann. Nucl. Energy 2017, 99, 372-382. [CrossRef]

73. Sua-iam, G.; Makul, N. Use of limestone powder during incorporation of Pb-containing cathode ray tube waste in self-compacting concrete. J. Environ. Manag. 2013, 128, 931-940. [CrossRef] [PubMed]

74. Shi, C.; Zheng, K. A review on the use of waste glasses in the production of cement and concrete. Resour. Conserv. Recycl. 2007, 52, 234-247. [CrossRef]

75. Ismail, Z.Z.; Al-Hashmi, E.A. Recycling of waste glass as a partial replacement for fine aggregate in concrete. Waste Manag. 2009, 29, 655-659. [CrossRef]

76. Zhao, H.; Poon, C.S.; Ling, T.C. Utilizing recycled cathode ray tube funnel glass sand as river sand replacement in the high-density concrete. J. Clean. Prod. 2013, 51, 184-190. [CrossRef]

77. Kim, I.S.; Choi, S.Y.; Yang, E.I. Evaluation of durability of concrete substituted heavyweight waste glass as fine aggregate. Constr. Build. Mater. 2018, 184, 269-277. [CrossRef]

78. Ouldkhaoua, Y.; Benabed, B.; Abousnina, R.; Kadri, E.-H.; Khatib, J. Effect of using metakaolin as supplementary cementitious material and recycled CRT funnel glass as fine aggregate on the durability of green self-compacting concrete. Constr. Build. Mater. 2020, 235, 117802. [CrossRef] 
79. Bawab, J.; Khatib, J.; Jahami, A.; Kenai, S.; Elkordi, A. Effect of using cathode-ray tubes (CRT) waste glass on concrete properties. BAU J. Sci. Technol. 2020, 2, 3 .

80. Romero, D.; James, J.; Mora, R.; Hays, C.D. Study on the mechanical and environmental properties of concrete containing cathode ray tube glass aggregate. Waste Manag. 2013, 33, 1659-1666. [CrossRef] [PubMed]

81. Park, S.B.; Lee, B.C.; Kim, J.H. Studies on mechanical properties of concrete containing waste glass aggregate. Cem. Concr. Res. 2004, 34, 2181-2189. [CrossRef]

82. Wang, J.; Guo, S.; Dai, Q.; Si, R.; Ma, Y. Evaluation of cathode ray tube (CRT) glass concrete with/without surface treatment. J. Clean. Prod. 2019, 226, 85-95. [CrossRef]

83. Donza, H.; Cabrera, O.; Irassar, E.F. High-strength concrete with different fine aggregate. Cem. Concr. Res. 2002, 32, $1755-1761$. [CrossRef]

84. Tan, K.H.; Du, H. Use of waste glass as sand in mortar: Part I-Fresh, mechanical and durability properties. Cem. Concr. Compos. 2013, 35, 109-117. [CrossRef]

85. Iniaghe, P.O.; Adie, G.U. Incorporation of finely ground waste cathode ray tube glass in concrete. J. Solid Waste Technol. Manag. 2017, 43, 207-215. [CrossRef]

86. Zhao, H.; Poon, C.S. A comparative study on the properties of the mortar with the cathode ray tube funnel glass sand at different treatment methods. Constr. Build. Mater. 2017, 148, 900-909. [CrossRef]

87. Ling, T.C.; Poon, C.S.; Lam, W.S.; Chan, T.P.; Fung, K.K.L. Utilization of recycled cathode ray tubes glass in cement mortar for X-ray radiation-shielding applications. J. Hazard. Mater. 2012, 199-200, 321-327. [CrossRef] [PubMed]

88. Yildirim, S.T. Research on strength, alkali-silica reaction and abrasion resistance of concrete with cathode ray tube glass sand. In Sustainable Buildings_Interaction between a Holistic Conceptual Act and Materials Properties; IntechOpen: London, UK, 2018; pp. 131-149.

89. Shayan, A.; Xu, A. Value-added utilisation of waste glass in concrete. Cem. Concr. Res. 2004, 34, 81-89. [CrossRef]

90. Song, W.; Zou, D.; Liu, T.; Teng, J.; Li, L. Effects of recycled CRT glass fine aggregate size and content on mechanical and damping properties of concrete. Constr. Build. Mater. 2019, 202, 332-340. [CrossRef]

91. Jóźwiak-Niedźwiedzka, D.; Lessing, P.A. High-density and radiation shielding concrete. In Developments in the Formulation and Reinforcement of Concrete; Elsevier: Amsterdam, The Netherlands, 2019; pp. 193-228.

92. Oliveira, L.A.P. De Mechanical and durability properties of concrete with ground waste glass sand. In Proceedings of the 1DBMC International Conference on Durability of Building Materials and Components, Istanbul, Turkey, 11-14 May 2008.

93. Walczak, P.; Małolepszy, J.; Reben, M.; Rzepa, K. Mechanical properties of concrete mortar based on mixture of CRT glass cullet and fluidized fly ash. Procedia Eng. 2015, 108, 453-458. [CrossRef]

94. El-Hosiny, F.I.; El-Faramawy, N.A. Shielding of gamma radiation by hydrated Portland cement-lead pastes. Radiat. Meas. 2000, 32, 93-99. [CrossRef]

95. Park, S.B.; Lee, B.C. Studies on expansion properties in mortar containing waste glass and fibers. Cem. Concr. Res. 2004, 34, 1145-1152. [CrossRef]

96. Limbachiya, M.C. Bulk engineering and durability properties of washed glass sand concrete. Constr. Build. Mater. 2009, 23, 1078-1083. [CrossRef]

97. Shi, C.; Wu, Y.; Riefler, C.; Wang, H. Characteristics and pozzolanic reactivity of glass powders. Cem. Concr. Res. 2005, 35, 987-993. [CrossRef]

98. Ling, T.C.; Poon, C.S. A comparative study on the feasible use of recycled beverage and CRT funnel glass as fine aggregate in cement mortar. J. Clean. Prod. 2012, 29-30, 46-52. [CrossRef]

99. Choi, Y.S.; Yang, E.I. Effect of calcium leaching on the pore structure, strength, and chloride penetration resistance in concrete specimens. Nucl. Eng. Des. 2013, 259, 126-136. [CrossRef]

100. Choi, S.; Choi, Y.S.; Won, M.-S.; Yang, E.I. Evaluation on the applicability of heavy weight waste glass as fine aggregate of shielding concrete. J. Korea Inst. Struct. Maint. Insp. 2015, 19, 101-108. [CrossRef]

101. Lee, D.-G.; Sung, N.-H.; Park, J.-H.; Chung, S.-H. An assessment of temperature history on concrete silo dry storage system for CANDU spent fuel. Ann. Nucl. Energy 2016, 94, 263-271. [CrossRef]

102. Liu, T.; Song, W.; Zou, D.; Li, L. Dynamic mechanical analysis of cement mortar prepared with recycled cathode ray tube (CRT) glass as fine aggregate. J. Clean. Prod. 2018, 174, 1436-1443. [CrossRef]

103. Ouldkhaoua, Y.; Benabed, B.; Abousnina, R.; Kadri, E. Experimental study on the reuse of cathode ray tubes funnel glass as fine aggregate for developing an ecological self-compacting mortar incorporating metakaolin. J. Build. Eng. 2020, $27,100951$. [CrossRef]

104. Ling, T.C.; Poon, C.S. Feasible use of recycled CRT funnel glass as heavyweight fine aggregate in barite concrete. J. Clean. Prod. 2012, 33, 42-49. [CrossRef]

105. Ling, T.C.; Poon, C.S. High temperatures properties of barite concrete with cathode ray tube funnel glass. Fire Mater. 2014, 38, 279-289. [CrossRef]

106. Youssf, O.; ElGawady, M.A.; Mills, J.E.; Ma, X. An experimental investigation of crumb rubber concrete confined by fibre reinforced polymer tubes. Constr. Build. Mater. 2014, 53, 522-532. [CrossRef]

107. Liu, H.; Shi, J.; Qu, H.; Ding, D. Feasibility of using recycled CRT funnel glass as partial replacement of high density magnetite sand in radiation shielding concrete. Trans. Nonferrous Met. Soc. China 2019, 29, 831-839. [CrossRef] 
108. Bawab, J.; Khatib, J.; Jahami, A.; Elkordi, A.; Ghorbel, E. Structural performance of reinforced concrete beams incorporating cathode-ray tube (CRT) glass waste. Buildings 2021, 11, 67. [CrossRef]

109. Liu, T.; Qin, S.; Zou, D.; Song, W. Experimental investigation on the durability performances of concrete using cathode ray tube glass as fine aggregate under chloride ion penetration or sulfate attack. Constr. Build. Mater. 2018, 163, 634-642. [CrossRef]

110. Australian Standard. AS 3600. Concrete Structures-Incorporating AMD 1: May 2002 and AMD 2; Australian Standard: Sydney, Australia, 2004.

111. Ling, T.C.; Poon, C.S. Use of recycled CRT funnel glass as fine aggregate in dry-mixed concrete paving blocks. J. Clean. Prod. 2014, 68, 209-215. [CrossRef]

112. Ling, T.-C.; Poon, C.-S. Use of CRT funnel glass in concrete blocks prepared with different aggregate-to-cement ratios. Green Mater. 2014, 2, 43-51. [CrossRef]

113. Ling, T.C.; Poon, C.S. Properties of architectural mortar prepared with recycled glass with different particle sizes. Mater. Des. 2011, 32, 2675-2684. [CrossRef]

114. Topçu, İ.B.; Boğa, A.R.; Bilir, T. Alkali-silica reactions of mortars produced by using waste glass as fine aggregate and admixtures such as fly ash and $\mathrm{Li}_{2} \mathrm{CO}_{3}$. Waste Manag. 2008, 28, 878-884. [CrossRef] [PubMed]

115. American Society of Testing Materials. ASTM C1260. Standard Test Method for Potential Alkali Reactivity of Aggregates (Mortar-Bar Method); American Society of Testing Materials: West Conshohocken, PA, USA, 2007.

116. Schwarz, N.; Cam, H.; Neithalath, N. Influence of a fine glass powder on the durability characteristics of concrete and its comparison to fly ash. Cem. Concr. Compos. 2008, 30, 486-496. [CrossRef]

117. Byars, E.A.; Zhu, H.Y.; Morales, B. Conglasscrete I: Final Report; Waste and Resources Action Programme: Banbury, UK, 2004.

118. Bursi, E.; Barbieri, L.; Lancellotti, I.; Saccani, A.; Bignozzi, M. Lead waste glasses management: Chemical pretreatment for use in cementitious composites. Waste Manag. Res. J. Sustain. Circ. Econ. 2017, 35, 958-966. [CrossRef] [PubMed]

119. Brouxel, $\mathrm{M}$. The alkali-aggregate reaction rim: $\mathrm{Na}_{2} \mathrm{O}, \mathrm{SiO}_{2}, \mathrm{~K}_{2} \mathrm{O}$ and $\mathrm{CaO}$ chemical distribution. Cem. Concr. Res. 1993, 23, 309-320. [CrossRef]

120. Kim, D.; Petrisor, I.G.; Yen, T.F. Evaluation of biopolymer-modified concrete systems for disposal of cathode ray tube glass. J. Air Waste Manage. Assoc. 2005, 55, 961-969. [CrossRef] [PubMed]

121. Kim, D.; Quinlan, M.; Yen, T.F. Encapsulation of lead from hazardous CRT glass wastes using biopolymer cross-linked concrete systems. Waste Manag. 2009, 29, 321-328. [CrossRef] [PubMed]

122. Long, W.-J.; Gu, Y.; Zheng, D.; Han, N. Utilization of graphene oxide for improving the environmental compatibility of cementbased materials containing waste cathode-ray tube glass. J. Clean. Prod. 2018, 192, 151-158. [CrossRef]

123. Long, W.-J.; Gu, Y.; Xing, F.; Khayat, K.H. Evaluation of the inhibiting effect of graphene oxide on lead leaching from waste cathode-ray tube glass incorporated in cement mortar. Cem. Concr. Compos. 2019, 104, 103337. [CrossRef]

124. U.S. Environmental Protection Agency. Test Method 1311. Toxicity Characteristic Leaching Procedure (TCLP); Specifications of the Committee on Analytical Reagents of the American Chemical Society; U.S. Environmental Protection Agency: Washington, DC, USA, 1992.

125. Phair, J.W.; Van Deventer, J.S.J. Effect of silicate activator $\mathrm{pH}$ on the leaching and material characteristics of waste-based inorganic polymers. Miner. Eng. 2001, 14, 289-304. [CrossRef]

126. Lin, T.T.; Lin, C.F.; Wei, W.C.J.; Lo, S.L. Mechanisms of metal stabilization in cementitious matrix: Interaction of tricalcium aluminate and copper oxide/hydroxide. Environ. Sci. Technol. 1993, 27, 1312-1318. [CrossRef]

127. Moon, D.H.; Dermatas, D. Arsenic and lead release from fly ash stabilized/solidified soils under modified semi-dynamic leaching conditions. J. Hazard. Mater. 2007, 141, 388-394. [CrossRef] [PubMed]

128. Tian, Y.L.; Liu, W.C.; Cui, S.P.; Sun, S.B.; Wang, Y.; Li, J.H.; Fu, Y.S.; Wang, J. Recycled CRT funnel glass as coarse aggregate and fine aggregate in the radiation protection concrete. Mater. Sci. Forum 2016, 847, 437-444. [CrossRef]

129. Gencel, O.; Koksal, F.; Ozel, C.; Brostow, W. Combined effects of fly ash and waste ferrochromium on properties of concrete. Constr. Build. Mater. 2012, 29, 633-640. [CrossRef] 